\title{
Evolution of mitochondrial relationships and biogeography of Palearctic green toads (Bufo viridis subgroup) with insights in their genomic plasticity
}

\author{
Matthias Stöck $^{\mathrm{a}, *}$, Craig Moritz ${ }^{\mathrm{a}}$, Michael Hickerson ${ }^{\mathrm{a}}$, Daniel Frynta ${ }^{\mathrm{b}}$, \\ Tatjana Dujsebayeva ${ }^{c}$, Valery Eremchenko ${ }^{d}$, J. Robert Macey ${ }^{\mathrm{a}}$, \\ Theodore J. Papenfuss ${ }^{\text {a }}$, David B. Wake ${ }^{\text {a }}$ \\ ${ }^{\text {a } U n i v e r s i t y ~ o f ~ C a l i f o r n i a, ~ B e r k e l e y, ~ D e p a r t m e n t ~ o f ~ I n t e g r a t i v e ~ B i o l o g y, ~ M u s e u m ~ o f ~ V e r t e b r a t e ~ Z o o l o g y ~(M V Z), ~}$ \\ 3101 Valley of Life Sciences Building \#3160, Berkeley, CA 94720-3160, USA \\ ${ }^{\mathrm{b}}$ Charles University, Department of Zoology, Viničná 7, 12844 Praha, Czech Republic \\ ${ }^{\mathrm{c}}$ Institute of Zoology, Laboratory of Ornithology and Herpetology, Al-Farabi Prospect 93, Almaty 480060, Kazakhstan \\ d Kyrgyz-Russian Slavic University, Bishkek 720000, Kievskaya Street 44, Kyrgyzstan \\ Received 2 February 2006; revised 19 May 2006; accepted 22 May 2006 \\ Available online 2 June 2006
}

\begin{abstract}
Taxa involving three bisexually reproducing ploidy levels make green toads a unique amphibian system. We put a cytogenetic dataset from Central Asia in a molecular framework and apply phylogenetic and demographic methods to data from the entire Palearctic range. We study the mitochondrial relationships of diploids to infer their phylogeography and the maternal ancestry of polyploids. Control regions (and $t R N A$ s between $N D 1$ and ND2 in representatives) characterize a deeply branched assemblage of twelve haplotype groups, diverged since the Lower Miocene. Polyploidy has evolved several times: Central Asian tetraploids (B. oblongus, B. pewzowi) have at least two maternal origins. Intriguingly, the mitochondrial ancestor of morphologically distinctive, sexually reproducing triploid taxa (B. pseudoraddei) from Karakoram and Hindukush represents a different lineage. We report another potential case of bisexual triploid toads (B. zugmayeri). Identical d-loops in diploids and tetraploids from Iran and Turkmenistan, which differ in morphology, karyotypes and calls, suggest multiple origins and retained polymorphism and/or hybridization. A similar system involves diploids, triploids and tetraploids from Kyrgyzstan and Kazakhstan where green toads exemplify vertebrate genomic plasticity. A new form from Sicily and its African sister species (B. boulengeri) allow internal calibration and divergence time estimates for major clades. The subgroup may have originated in Eurasia rather than Africa since the earliest diverged lineages (B. latastii, B. surdus) and earliest fossils occur in Asia. We delineate ranges, contact and hybrid zones. Phylogeography, including one of the first non-avian datasets from Central Asian high mountains, reflects Quaternary climate and glaciation.
\end{abstract}

(C) 2006 Elsevier Inc. All rights reserved.

Keywords: Polyploidy; d-loop; Phylogeny; Population genetics; Palearctic; Phylogeography

\section{Introduction}

Gene and genome duplications are a major source of evolutionary innovation and diversity. In vertebrates, two

\footnotetext{
* Corresponding author. Present address: Department of Ecology and Evolution, University of Lausanne, Biophore - Quartier Sorge, CH 1015 Lausanne, Switzerland. Fax: +41216924165.

E-mail address: matthias.stoeck@web.de (M. Stöck).
}

aspects can be distinguished: (i) whole genome doubling during early evolution (Ohno, 1970) with accumulating evidence (e.g. Meyer and Schartl, 1999; Taylor and Raes, 2005; McLysaght et al., 2002; Furlong and Holland, 2002; Jaillon et al., 2004), including number and history of duplications (Dehal and Boore, 2005). (ii) More recently evolved polyploids, which provide an opportunity to understand the evolutionary consequences of large genomic changes. In animals, recent polyploids (Gregory and 


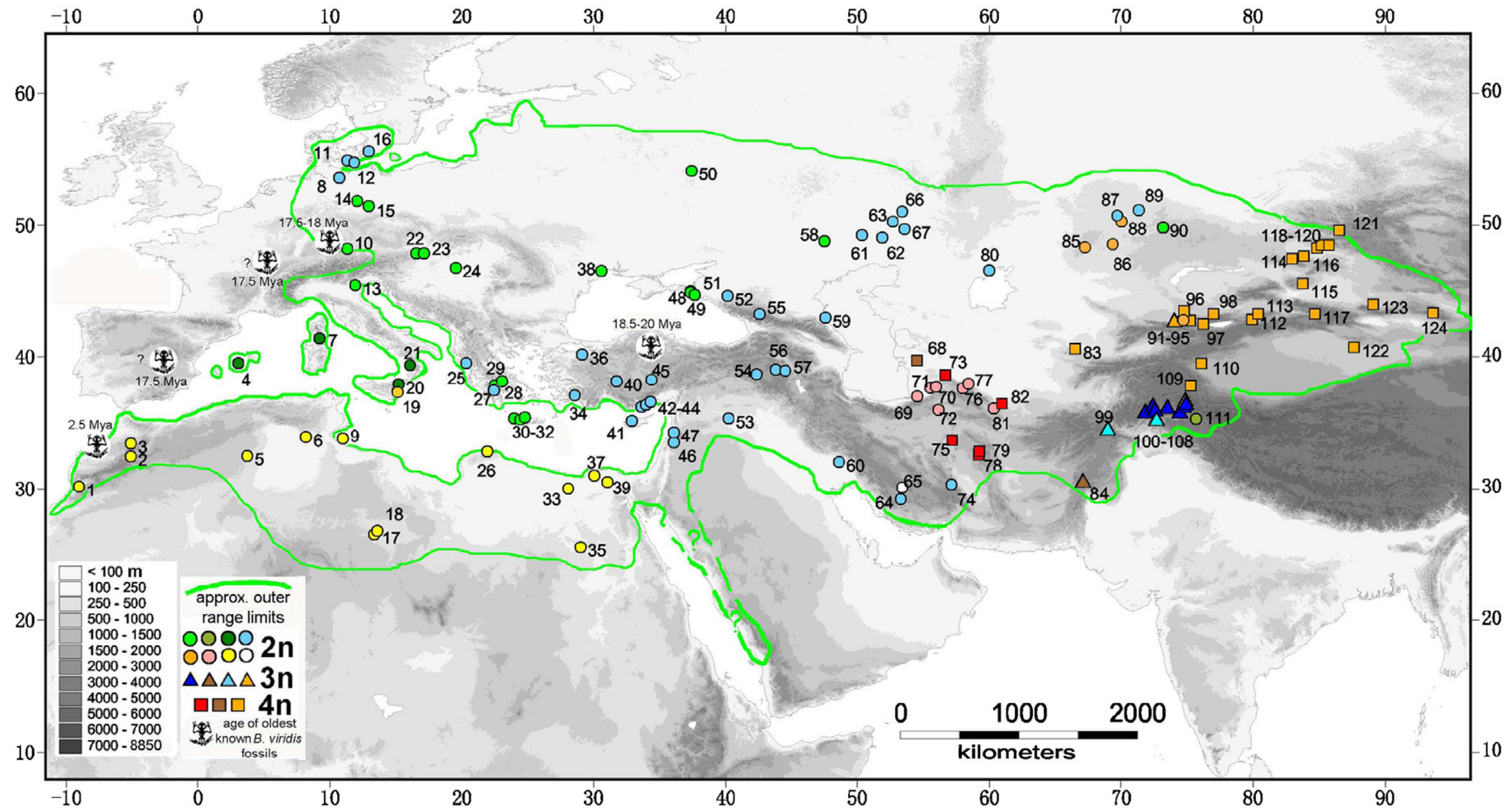

Fig. 1. Geographic range of the Bufo viridis subgroup with sampling localities and sites of oldest known fossils of the B. viridis subgroup. See legend and Appendix A for locality IDs. Approximate range limits after Balletto et al. (1985), Bons and Geniez (1996), Gasc et al. (1997), Borkin (1999), Kuzmin (1999), Schleich et al. (1996), and Stöck et al. (2001a,b). 
Mable, 2005) are known among turbellarians, annelids, mollusks, insects and crustaceans. Among vertebrates, cytogenetic studies revealed numerous clades of polyploids in teleosts (Schultz, 1980; Le Comber and Smith, 2004), amphibians and reptiles (Bogart, 1980), but not in mammals (Contreras et al., 1990; Svartman et al., 2005). Natural polyploids are especially frequent in amphibians in which they evolved in Urodela and Anura (Bogart, 1980; Schmid, 1980; Kawamura, 1984; Vences and Wake, in press).

A challenge for the formation of polyploid animals is the duplication of sex determining loci (for a recent discussion: Mable, 2004; Coyne and Orr, 2004), often resulting in deviations from sexual and/or meiotic reproduction. In vertebrates, reproductive modes without (so far identified forms of) recombination are parthenogenesis (Suomalainen et al., 1987; Dawley and Bogart, 1989; Simon et al., 2003) and gynogenesis (Beukeboom and Vrijenhoek, 1998). True parthenogenesis among vertebrates is apparently restricted to reptiles with all-female clones producing identical daughters that lack any paternal contribution. In gynogenesis, found in fishes and amphibians, embryogenesis is triggered by sperm from allo-specific males, but usually without their genetic input. "Hybridogenetic reproduction in a broad sense" (Stöck and Lamatsch, 2002) can be termed different hemiclonal (Schultz, 1969) and meroclonal (Vinogradov et al., 1990) mechanisms, characterized by elimination of complete chromosome sets and clonal or meiotic inheritance of the remaining sets (e.g. Alves et al., 2001; Günther et al., 1979; Günther, 1990; Stöck et al., 2002). Remarkably, several vertebrate complexes (mainly fishes, amphibians and few reptiles) include animals of various ploidy levels and show common occurrence of these main reproductive modes, in which clonal, hemiclonal and/or meroclonal as well as sexual mechanisms contribute to genetic diversity, interaction of ploidy levels and evolution (e.g. Darvesky et al., 1989; Alves et al., 2001; Günther, 1990; Zhou et al., 2000; Bogart and Klemens, 1997; Goddard et al., 1998; Bogart, 2003; Rab et al., 2000; Vasilev et al., 2003; Ogielska et al., 2004; Plötner, 2005). This genomic diversity and plasticity and in some systems the interaction of individuals with sexual and asexual reproduction makes them ideal systems to address an enormous variety of evolutionary questions. This includes consequences of gene and genome doubling, evolutionary genetics of hybridization with the interplay of two or more foreign genomes in one nucleus and one organism, hybrid fertility and fitness, sex determination, occurrence or absence of meiosis, crossing over and consequences of the partial loss, or maintenance, of recombination, and finally hybrid ("recombinational", Coyne and Orr, 2004, or "collective" Morjan and Rieseberg, 2004) speciation and evolution.

In this comparative context green toads of the Palearctic Bufo viridis subgroup (Borkin, 1999; Stöck et al., 2001a) stand out. They are the only known complex of amphibians that comprises diploid (2n), ${ }^{1}$ tetraploid (4n; Mazik et al., 1976) and even triploid (3n; Stöck et al., 1999, 2002) bisexually reproducing taxa. Whereas $2 \mathrm{n}$ and $4 \mathrm{n}$ toads reproduce meiotically, one of the three chromosome sets of South Asian 3n Bufo pseudoraddei seems neither to participate in crossing over nor in random segregation (recombination) during meiosis but rather is clonally inherited (females) or eliminated (males; Stöck et al., 2002), a mechanism related to hybridogenesis. In High Asia, i.e. in the eastern Pamirs, Karakoram, Hindukush and western Himalayas, green toad taxa of all three ploidy levels occur allopatrically in similar high mountain environments (Stöck et al., 2001b). Cytogenetic data (Stöck et al., 2005) suggest that Central Asian 4ns have evolved independently at least twice, and there is morphological evidence for two separate $3 \mathrm{n}$ taxa (Stöck et al., 2001a).

For the Asian green toads, we use the nomenclature as revised by Stöck et al. (2001a) who provided information on name-bearing types, type localities, nomenclatural and systematic histories, ploidy level, bioacoustics, distribution, proposed current taxonomic status, and a tentative identification key. Among diploid toads, they tentatively distinguished the taxa: (1) B. viridis with nominal subspecies $B$. $v$. kermanensis, B. v. shaartusiensis, B. v. turanensis and B.v. ssp. [formerly "arabicus"]), and (2) B. latastii latastii. They recognized two tetraploid species: (I) B. oblongus Nikolsky, 1896, with B. o. oblongus and B. o. danatensis-provisionally called "Western Central Asian Tetraploids", and (II) B. pewzowi Bedriaga, 1898, with nominal subspecies B. p. pewzowi, B. p. unicolor, B. p. strauchi and B. p. taxkorensis,- - termed "Eastern Central Asian Tetraploids". In the literature of the 1980s and 1990s, all Central Asian tetraploids (now B. oblongus, B. pewzowi) were mostly called "B. danatensis", a younger subjective synonym of Bufo oblongus. Bisexual triploid taxa are represented by B. pseudoraddei (Mertens, 1972), with B.p.pseudoraddei and $B$. p. baturae. Because of contradictory data or unknown ploidy, the status of $B$. asiomontanus and B. zugmayeri remained unclear (further details: Stöck et al., 2001a).

The polytypic B. viridis subgroup (sensu Stöck et al., 2001a, see Section 4) inhabits an enormous Palearctic range, and previous morphological and general biogeographic knowledge suggest the occurrence of multiple

\footnotetext{
1 Abbreviations used: 2n, diploid; 4n, tetraploid; 3n, triploid; 2ns, diploids; 3ns, triploids, 4ns, tetraploids; LGM, last glacial maximum of the Pleistocene; MRCA, most recent common ancestor; My, Million years, Mya, million years ago; ML, Maximum likelihood analysis, MP, Maximum Parsimony analysis; MB, Bayesian analysis using MrBayes; mtDNA, mitochondrial DNA; BMNH, British Museum of Natural History London, United Kingdom; MTD, Museum Tierkunde Dresden, Germany; MVZ, Museum of Vertebrate Zoology, University of California, Berkeley, USA; ZSM, Zoologische Staatsammlung Munich, Germany, HNHM, Hungarian National History Museum, Budapest, Hungary; ZFMK, Zoologisches Forschungsinstitut und Museum Alexander Koenig, Bonn, Germany; CUP, Charles-University, Praha, Czech Republic; NME, Naturkundemuseum Erfurt, Germany; CAS, California Academy of Sciences, San Francisco, USA; CS, Collection Schmidtler, private collection (will be transferred to ZSM) of Josef Friedrich Schmidtler, Munich, Germany.
} 


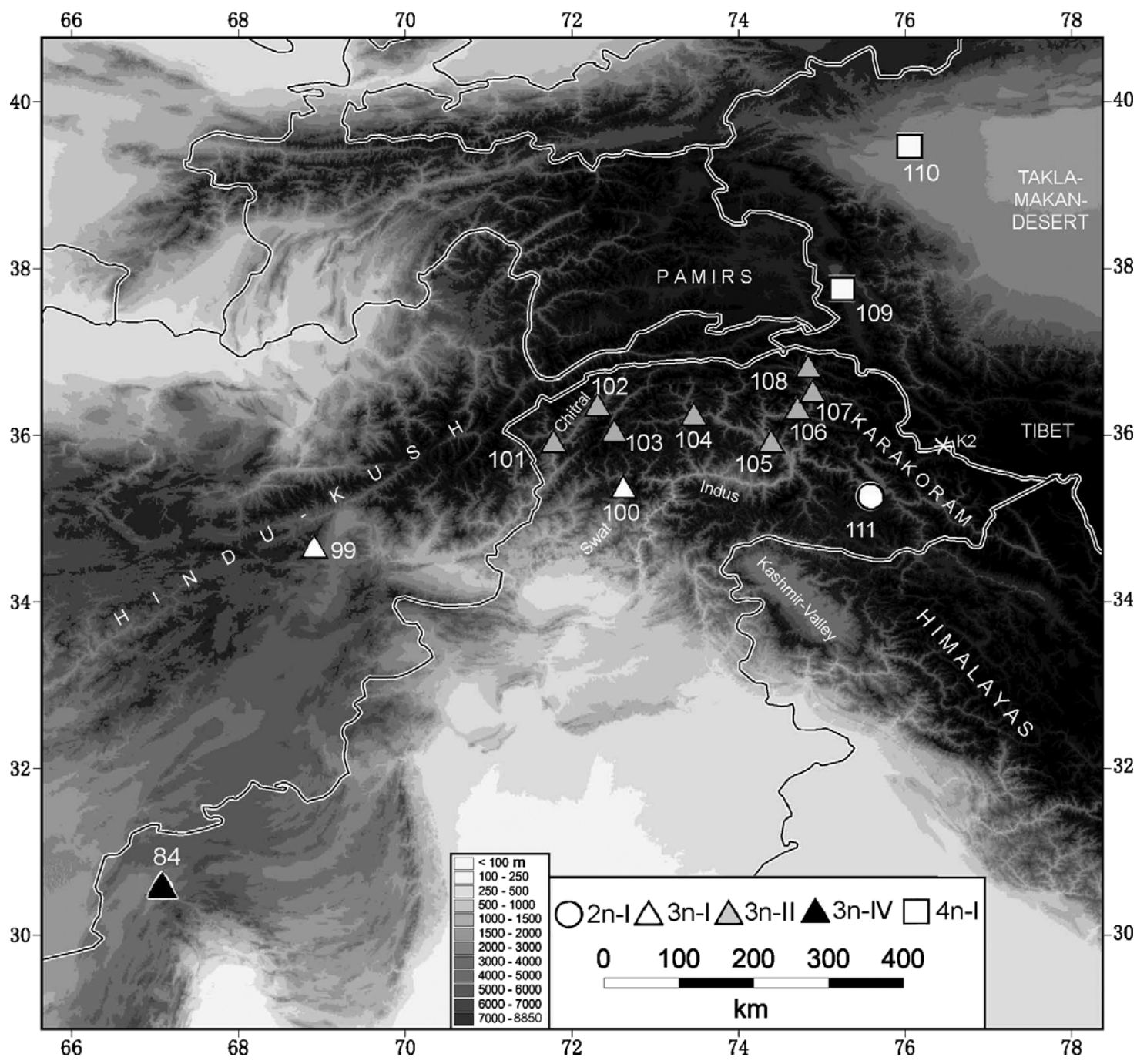

Fig. 2. Geographic range of the Bufo viridis subgroup in High Asia with sampling localities. See legend and Appendix A for locality IDs.

lineages, as there has been no range-wide analysis of molecular variation. Consequently, a first step towards the understanding of the evolution of the subgroup is to generate a comprehensive phylogenetic and phylogeographic hypothesis of the $2 \mathrm{n}$ lineages, and to analyze the mitochondrial relationships of the polyploids.

Two hypothesis can be tested: (i) The bisexually reproducing $3 \mathrm{n}$ south of the Karakoram-Hindukush watershed and the $3 n$ forms in north central Asia, geographically close to $2 n$ and $4 \mathrm{n}$ toads, are derived from the same recent mitochondrial ancestor or (ii) all these forms represent descendents of several polyploidizations involving different lineages.

In this paper, we present mtDNA evidence for separate matrilineal ancestry of $3 \mathrm{n}$ B. pseudoradde $i$ and 4n Central
Asian polyploid taxa (B. pewzowi, B. oblongus) and report the discovery of a new likely sexually reproducing $3 \mathrm{n}$ taxon (B. zugmayeri), which also belongs to the Central Asian lineage. Our phylogeographic analysis of this subgroup also provides a comparative historic biogeographic perspective derived from one of the most widespread amphibian complexes of the Palearctic realm.

\section{Materials and methods}

\subsection{Sampling, DNA extraction, PCR conditions}

A total of 325 specimens [135 2ns (+2 presumably $2 \mathrm{~ns})$, $1143 \mathrm{~ns}$ ( +3 presumably $3 \mathrm{~ns}$ ), $714 \mathrm{~ns}$ ] of the $B$. viridis sub-

Fig. 3. Phylograms resulting from a Bayesian analysis of d-loop sequences (left) and a ML-analysis of $N D+t R N A$ s (right). D-loop tree (left): ploidy levels (e.g. 4n), sample ID (max. three digits, see Appendix A), and locality ID as in (Figs. 1 and 2). $F_{1}$ individuals resulting from crosses are designated by a "C" or "Hy" instead of a locality ID. Note potentially applicable taxon names for many groups. Color-labeled individuals in the d-loop tree (left) are identical to those that yielded the $N D+t R N A$ sequences for the tree on the right. Groups A-C all belong to the "Central Asian clade". For both trees, Bayesian posterior support values are shown above major nodes $(*=100)$, below Maximum likelihood bootstrap values $(N D+t R N A \mathrm{~s})$. For the Central Asian Clade, Q-banded chromosomes 6 of two tetraploid forms (B. oblongus, B. pewzowi) are depicted. 


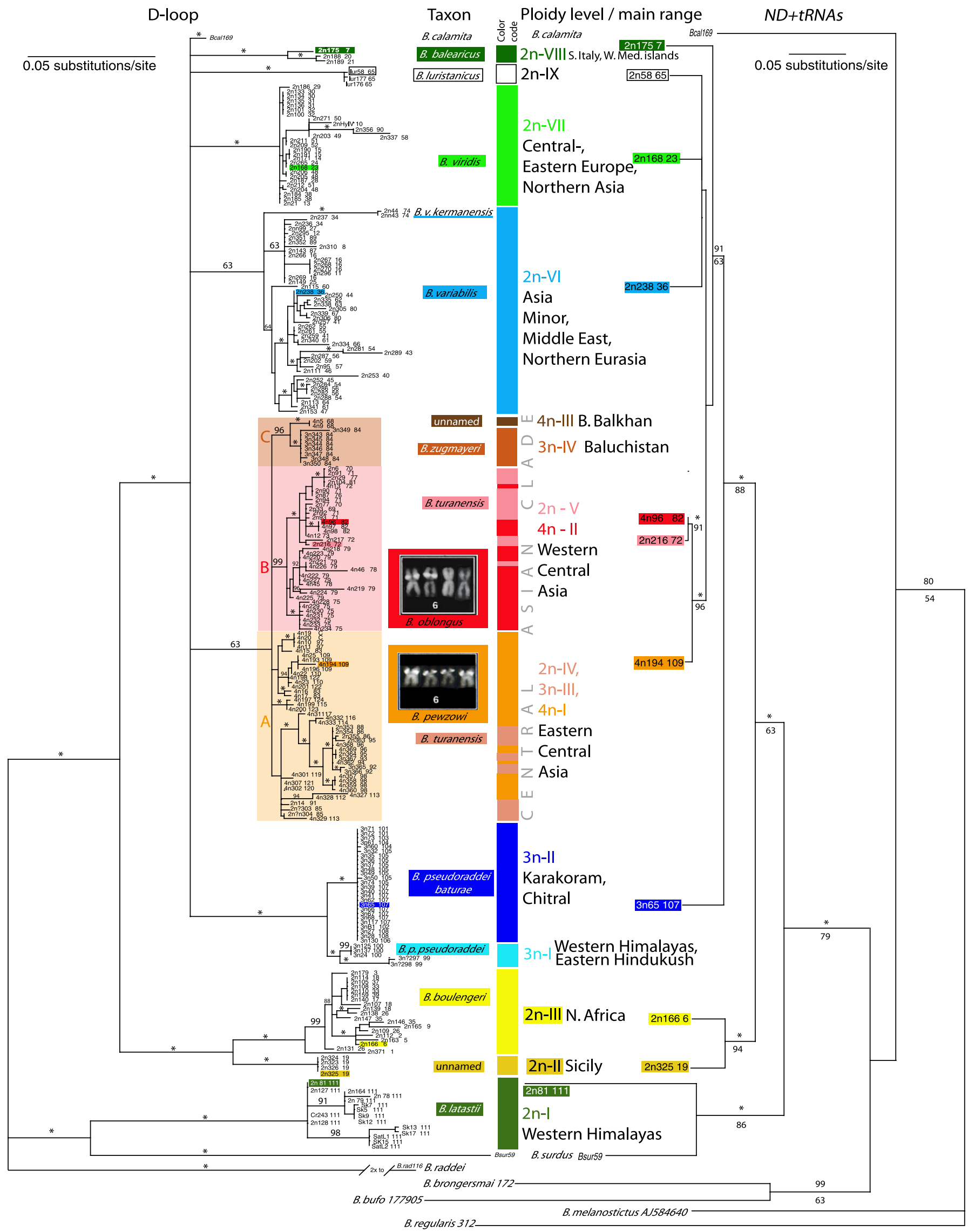


group, originating from 124 ( 85 for $2 n, 11$ for $3 n, 28$ for $4 n$ ) localities (Figs. 1 and 2) throughout the Palearctic range were included (see Appendix A). For most toads from the range of the polyploids we have karyotypic as well as microdensitometric or flow cytometric data on ploidy of sequenced specimens (Stöck, 1997, 1998a,b, Stöck et al., 1999-2005). Several additional specimens were karyotyped (data not shown). Green toads from the $B$. viridis subgroup, which occur west of a line between western Iran and northwestern Kazakhstan, were considered $2 \mathrm{n}$ because no previous study has revealed polyploids (Borkin, 1999; Stöck et al., 2001b), except as rare accidental cases (Odierna et al., 2004) presumably resulting from unreduced ova (Bogart, 1972). In addition, diploidy of several green toads from North Africa was confirmed by flow cytometry. If no ploidy data were available, all samples east of $80^{\circ} \mathrm{E}$ were considered $4 \mathrm{n}$, because neither $2 \mathrm{n}$ nor $3 \mathrm{n}$ have been detected in that region (Borkin et al., 2001; Stöck et al., 2001b). In a small number of cases, tissue samples from remote localities without ploidy information were included. Toads were collected by the authors or provided by natural history museums and many colleagues (see Acknowledgements). We also included crosses $\left(\mathrm{F}_{1}\right)$ resulting from two chromosomally different $4 \mathrm{n}$ taxa $(B$. oblongus father $\times B$. pewzowi mother), from 3n (B. pseudoraddei baturae father) with $2 \mathrm{n}$ (B. latastii mother) toads obtained in the laboratory, and from a natural cross $(B$. calamita father $\times B$. v. viridis mother), in order to test for maternal inheritance of the mitochondrial marker. All tested $F_{1}$ from these three interspecies crosses (Appendix A for details) shared their marker with their mothers (Fig. 3: "C", "Hy") and confirmed that d-loop sequences represent authentic mtDNA. Many specimens from the $3 \mathrm{n}$ B. pseudoraddei baturae and $2 \mathrm{n} B$. latastii were released after blood sampling but vouchers are available from these and many other populations (Appendix A). From some localities, toe clips or tail tip samples of tadpoles were used. In order to test for common ancestry and maternal contribution to the formation of polyploids of the $B$. viridis subgroup, we also sequenced d-loops and $N D+t R N A$ s of several taxa previously considered to be related or even closely related members of the subgroup ( $B$. arabicus, $B$. brongersmai, B. calamita, B. luristanicus, B. mauritanicus, B. raddei, B. surdus and B. stomaticus). While $B$. raddei served as the "outgroup" taxon for the phylogenetic analyses of the d-loops, $B$. regularis was used for rooting the " $N D+t R N A \mathrm{~s}$ " tree (see below).

Genomic DNA was extracted from frozen or ethanol preserved blood, liver, muscle tissue, pooled organs (tadpoles) and muscle of vouchers from scientific collections using a phenol-chloroform extraction ( $\sim 20 \%$ of samples) or the Quiagen DNeasy ${ }^{\mathrm{TM}}$ kit. About 880 bp were amplified, comprising most of the mitochondrial control region ( = "dloop"; primers ControlB-H, CytbA-L; PCR: $96^{\circ} \mathrm{C}, 2 \mathrm{~min}$, denaturation; $52^{\circ} \mathrm{C}, 45 \mathrm{~s}$, annealing; $72^{\circ} \mathrm{C}, 2 \mathrm{~min}$, extension; cycle $\left[94^{\circ} \mathrm{C}, 30 \mathrm{~s}\right.$, denaturation, $52^{\circ} \mathrm{C}, 45 \mathrm{~s}$ annealing, $72^{\circ} \mathrm{C}$, $1.5 \mathrm{~min}$, extension $] 38$ times; $72^{\circ} \mathrm{C}$, final extension, $5 \mathrm{~min}$; Goebel et al., 1999). In representatives from most clades (and ploidy levels), as revealed from analyses of d-loop sequences (see below), as well of B. calamita, B. brongersmai, $B$. bufo and B. regularis, we sequenced an additional 1100 bases of mtDNA extending from $N D 1$ through the $t R N A^{\mathrm{Ile}}$, $t R N A^{\mathrm{Gln}}$, and $t R N A^{\mathrm{Met}}$ genes to $N D 2$ (termed " $N D+t R N A \mathrm{~s}$ " here), as described by Macey et al. (1998a,b). All PCR-products were sequenced in both directions on an ABI 3730 sequencer. Sequences were aligned using Sequencher, v. 4.1.2 and adjusted by eye using MacClade 4.06.

\subsection{Phylogenetic and phylogeographic analysis}

The complete alignment of d-loop sequences comprised 898 characters. Because of questionable alignment, characters 125-166 were excluded from the analyses. We applied MrModeltest (vers. 2.0 modified from Modeltest, Posada and Crandall, 1998, by J.A. Nylander, Uppsala Univ., Sweden) for determining the best fitting model of sequence evolution $(\mathrm{HKY}+\mathrm{I}+\mathrm{G}, \mathrm{AICE})$. We inferred phylogeny with Bayesian statistics (MB, MrBayes v. 3.0b4; Huelsenbeck and Ronquist, 2001), running four chains for 10 million generations, with tree sampling every 1000 generations. We also estimated relationships using neighbor joining (NJ, 1000 bootstrap pseudoreplicates) and parsimony methods (MP, 100 bootstrap steps) as implemented in PAUP, vers. $4.0 \mathrm{~b} 10$ (Swofford, 2002). For analysis of $N D+t R N A \mathrm{~s}$, we used ML-settings from Modeltest in PAUP $(\mathrm{HKY}+\mathrm{I}+\mathrm{G}$, $\mathrm{Nst}=2$, TRatio $=6.7648$, Rates $=$ gamma Shape $=0.7208$, Pinvar $=0.5616,100$ bootstrap steps). For some d-loop clades, we used the parsimony-based network analyses program TCS (vers. 1.18, Clement et al., 2000).

\subsubsection{Genealogical analysis, estimations of evolutionary rates and minimum divergence times}

We estimated the age of population expansion for green toad groups as found in a certain geographical region using Fluctuate (Kuhner et al., 1998) by obtaining maximum likelihood estimates for $\theta(2 N \mu$; $\mu$ is DNA substitution rate per site per generation, $N$ is the current female effective population size) and $g$ (the historical exponential growth parameter). Repeated analyses to ensure stability of estimates were run with random seeds, 10 short Monte Carlo chains of 4000 steps, and five long chains of 20,000 steps. Growth was inferred using logarithmic likelihood ratio tests with one degree of freedom (Huelsenbeck and Rannala, 1997). If a nogrowth model was rejected, $g$ values were used to approximate the time at which effective population size was $10 \%$ of the current effective size by applying our DNA substitution estimate. Estimates of exponential growth $\left(g\right.$ in units of $\left.\mu^{-1}\right)$ were used to approximate population size at time $t$ in the past from $N_{t}=\theta^{\mathrm{e}-(g \mu) t}$ where $N_{t}$ is the effective size at time $t$ in the past (Kuhner et al., 1998; Wares and Cunningham, 2001). Using this equation, $t$ was estimated by substituting $N_{\mathrm{t}}$ with $N_{t} / N_{t=0}=0.1$. We also calculated Tajima's D using the program Arlequin 2.000 (Schneider et al., 2000). For each estimate we define a population by the geographical region in which a clade is found. We assume that the time at which the effective size was $10 \%$ is an approximation of a population's 
minimum age. We also assume that each clade's current distribution encompasses its place of origin, and that each clade is defined by an ancestral haplotype and all regional descendants. As another indication of population growth, we report Tajima's D, which is expected to be significantly negative under demographic expansion or a recent selective sweep at a linked locus (Tajima, 1989).

Estimated rates of anuran mtDNA-substitution (Macey et al., 1998a,b), comparisons of coding and d-loop-mtDNA (Liu et al., 2000; Sumida et al., 2000) and major geological events such as the last connection of Africa and Europe and the fossil record served for rough calibrations. We estimated the d-loop (and $N D+t R N A$ ) rate(s) by assuming that the last landbridge between North Africa and Sicily broke off about 5.3 Mya, i.e. the Strait of Sicily was formed at the end of the Messinian salinity crisis at the Miocene/ Pliocene boundary (e.g. Jaeger et al., 1987; Krjigsman et al., 1999; Butler et al., 1999; Dobson and Wright, 2000; F. Rögl pers. comm.). By comparing populations from north and south of the Strait of Sicily, d-loop and $N D+t R N A$ rates were estimated from the average pairwise genetic divergences between the respective samples using the best fitting substitution model (Modeltest). Because the mtDNA MRCA is likely to precede the population divergence (Arbogast et al., 2002), we corrected d-loop sequence divergence for ancestral polymorphism by assuming that the ancestral divergence is equivalent to the divergence found in current African samples. Using this rate estimate, other divergence times among pairwise regional groups were estimated with $\mu=\left(\pi_{\mathrm{b}}-\pi_{w}\right) / 2 \tau$, where $\tau$ is the divergence time, $\mu$ is the DNA substitution rate per locus per generation, $\pi_{\mathrm{b}}$ is the average number of pairwise differences between sampled populations, and $\pi_{\mathrm{w}}$ is the average number of pairwise differences within populations (Nei and $\mathrm{Li}, 1979$ ). In all cases, pairwise genetic distances were based on the best-fit model of DNA evolution. This method assumes migration among regions to be negligible, a reasonable assumption given regional monophyly. Divergence times were estimated among all green toad "regional taxa", defined by the most inclusive haplotype clades associated with major geographic regions. We also conducted log-likelihood ratio tests (Huelsenbeck and Rannala, 1997) using PAUP to test for a molecular clock in D-loop and in $N D+t R N A$ s alignments using different Bufo-species as outgroups and tested these in Bayesian and ML-trees, respectively.

\section{Results}

Bayesian, NJ, and MP analyses distinguished twelve major mitochondrial clades (d-loop), most of which are well supported and differ substantially from each other (Fig. 3). In clades of diploids and clades containing polyploids both mitochondrial markers reflect deep divergences in an old group with substantial structure and up to $\sim 30 \%$ divergence, and $>2 \%$ between the youngest sister clades (Table 1). Most clades are distributed allo- or parapatrically. Only two $2 \mathrm{n}$ clades (2n-VI, $2 \mathrm{n}$-VII) exhibit apparent wide range overlap (Fig. 1). Polyploids belong to two major clades, the 'Central Asian clade' (Fig. 3) and the clade comprising two nominal subspecies of $3 n$ B. pseudoraddei (3n-I, $3 n-I I)$. The geographic distribution of clades (Fig. 1) reflects the expected higher genetic diversity in the south than in the north, with all clades present between $30^{\circ}$ and $40^{\circ}$ but only three between $45^{\circ}$ and $55^{\circ} \mathrm{N}$.

Likelihood ratio tests for clocklike evolution were sensitive to different outgroup species, suggesting difficulties in estimating the correct model of sequence evolution and/or correct alignment. When the $N D+t R N A \mathrm{~s}$ ML-tree for all green toads was rooted with $B$. calamita, clocklike evolution was found. We estimated divergence for the $\mathrm{Pi}_{\mathrm{NET}}$ rate $=$ 0.06777 per d-loop per $5.3 \mathrm{My}$ (ca. $1.278 \%$ divergence per $\mathrm{My}), \mathrm{Pi}_{\text {BTw }}$ rate $=0.08712$ per d-loop per $5.3 \mathrm{My}$ (ca. $1.644 . \%$ divergence per $\mathrm{My})$ and the $\mathrm{Pi}_{\mathrm{BTw}}$ rate $=0.0571$ per $N D+t R N A$ s (ca. $1.077 \%$ divergence per My).

Below, we characterize the various clades based on ploidy, geographic ranges and/or taxonomic identity using the Bayesian d-loop phylogram (Fig. 3).

\subsection{Groups of diploid green toads}

Mitochondrial DNA of the $2 \mathrm{n}$ taxa belongs to nine major clades which cover the entire Palearctic range with the exception of the Asian high mountain and eastern continental desert areas that are dominated by polyploids ( $3 \mathrm{n}$, $4 n)$.

\subsubsection{2n-I Western Himalayas}

MtDNA of the geographically isolated high mountain 2n Bufo latastii from the western Himalayas (Ladakh, loc. 111 ) is most closely related to that of a single specimen of the poorly known $B$. surdus, and both form an early diverged sister group to all remaining green toad mitochondrial lineages. Bufo latastii exhibits slight chromosomal differences but close bioacoustic and morphological affinities to other B. viridis subgroup taxa (Dubois and Martens, 1977; Stöck et al., 2001a). Substantial haplotype structure in clade $2 n-I$ may be explained by an origin of toads from different tributaries of the Indus, which meet at Skardu/ Ladakh (loc. 111). A zero growth model could not be rejected by Fluctuate and Tajima's D (0.096). This lineage is of considerable age and might have diverged from the mtDNA-lineage to all remaining green toads more than 20 Mya (Table 1).

\subsubsection{2n-II Southeastern Sicily}

Four identical d-loop sequences of unnamed green toads from the San Leonardo river in southeastern Sicily (loc. 19), isolated by the Mt. Etna massif from northern Sicily (loc. 20 of $2 \mathrm{n}$-VIII), represent a sister clade to the mtDNA of all African green toads (2n-III). This old relationship is also confirmed by the $N D+t R N A$ s (Fig. 3) and was used to calibrate the divergence time estimates, assuming the most recent common ancestor (MRCA) with clade 2n-III may have existed at least 5.3 Mya. 
Table 1

Average divergence between different groups of toads and minimum divergence time estimates based on mitochondrial sequences

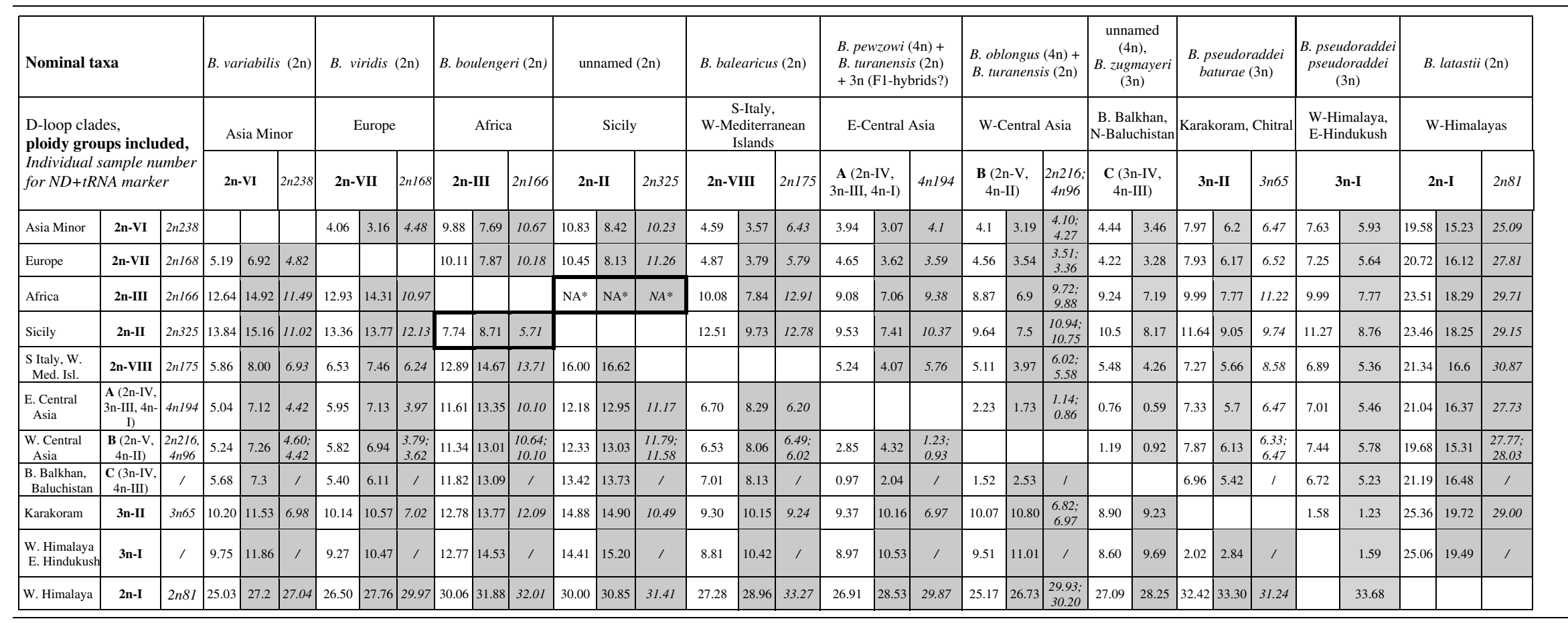

Upper right triangle: Minimum divergence time estimates (My); light columns: estimates based on divergence rate $\mathrm{Pi}_{\mathrm{NET}}$ rate $=0.067765$ per d-loop per $5.3 \mathrm{My}$ [ca. $1.278 \%$ divergence per My]; gray columns: estimates based on divergence rate $\mathrm{Pi}_{\mathrm{BTw}}$ rate $=0.08711833$ per d-loop per $5.3 \mathrm{My}$ [ca. $1.644 \%$ divergence per My]; gray columns with numbers in italics: $\mathrm{Pi}_{\mathrm{BTw}}$ rate $=0.05710676$ per $N D+t R N A s$ [ca. 1.077\% divergence per My]; dark frame marks sister relationship used for calibration. Lower left triangle: Average divergence between groups (\%), light columns: Pi ${ }_{\mathrm{NET}}$ distances; gray columns: $\mathrm{Pi}_{\text {BTW }}$ distances.

${ }_{*}^{*}$ Because the four Sicilian samples lacked any sequence differences and the ancestral polymorphism was likely more similar to the current African sample, we based the $\pi_{\mathrm{w}}$ value on this only. 


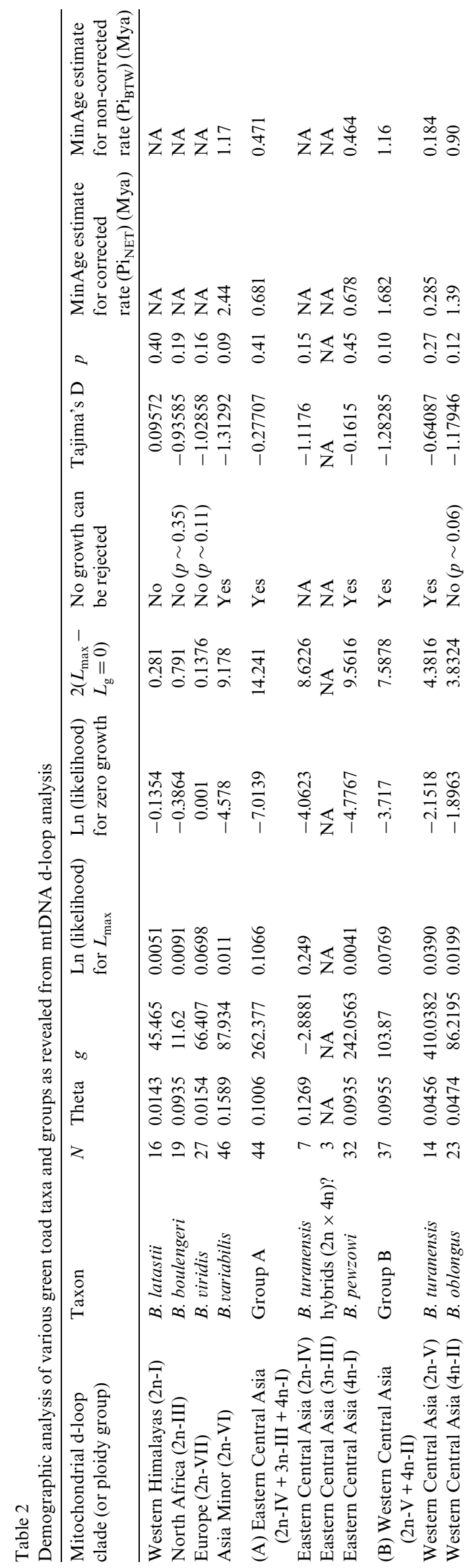

\subsection{3. $2 n-I I I 2 n$ North Africa}

Toads from western Morocco to eastern Egypt differ substantially from the geographically nearest diploids in the Middle East (e.g. loc. 46, 47), and 2n toads (2n-VIII) on western Mediterranean islands (loc. 4, 7, 20) and in southern Italy (loc. 21). However, clade 2 n-III is sister taxon to Sicilian 2n-II. Neither Fluctuate nor Tajima's D reflected population growth (Table 2). The sister clades $2 \mathrm{n}$-II and $2 \mathrm{n}$ III form a well-supported group, which is the sister taxon to all $2 \mathrm{n}, 3 \mathrm{n}$ and $4 \mathrm{n}$ green toads [except $B$. latastii $(2 \mathrm{n}-\mathrm{I})$ and $B$. surdus] and probably diverged from these between 7 and 12 Mya (Table 1). The application of the name Bufo boulengeri Lataste, 1879 [nomen nudum according to Frost, 2004] to African green toads is justified because the B. boulengeri type is extant in BMNH (Clarke, pers. comm.).

\subsubsection{Diploids in the Central Asian clade}

For analyses of maternal ancestry of the two $4 n$ taxa, we divided the Central Asian clade into three groups (Fig. 3: groups $\mathrm{A}-\mathrm{C}$ ), mainly based on specific chromosomal characters in each of the $4 \mathrm{n}$ taxa in groups A and B (see below). This approach also results in a somewhat artificial subdivision into two diploid groups $(2 n-I V, 2 n-V)$, whose differences may simply reflect isolation by distance. The name $B$. turanensis is applied (Stöck et al., 2001a) to these large-sized diploid toads (2n-IV, $2 n-V)$, but data from the type locality (Dushanbe, Tajikistan) are lacking.

3.1.4.1. $2 n-I V$ Eastern Central Asia. Diploid toads in this paraphyletic group A were detected in the semi-desert and steppe of northern Kazakhstan (loc. 85, 86, 88) and $\mathrm{N}$ to the Tian-Shan of northern Kyrgyzstan (loc. 91, 94). Analysis of seven d-loops of 2 ns provided a negative value for growth $(g=-2.88$, Fluctuate) but also negative Tajima's D (close to significance). The mtDNA phylogeny is tightly intertwined with groups 3n-III and 4n-I (B. pewzowi) of the same region. We treat them as a paraphyletic "group A" (Figs. 3 and 4). The closest relatives of group A are clades B $(2 n-V+4 n-I I)$ and C $(4 n-I I I+3 n-I V)$, with which they form the moderately supported "Central Asian clade" (Fig. 3).

3.1.4.2. $2 n-V$ Western Central Asia. Mitochondrial sequences of $2 \mathrm{n}-\mathrm{V}$ in northeastern Iran (loc. 69-72) and the Kopet Dagh range of eastern Iran and western Turkmenistan (loc. $76,77,81)$ show high growth values $(g=410)$ based on Fluctuate and a negative Tajima's D ( -0.64 ; but not significant) and suggest expansion of this population, an event that dates between $\sim 0.2$ and 0.3 Mya. This is only half the estimated (expansion) age of the partly syntopic $4 \mathrm{n}-\mathrm{II}$ (see below). The $2 \mathrm{n}-\mathrm{V}$ individuals cluster together with those of $4 \mathrm{n}-\mathrm{II}$ (B. oblongus), with which they form subclade B.

\subsubsection{2n-VI Asia Minor, Middle East and northern Eurasia}

This is the only haplotype group found in Anatolia. It also occurs on Cyprus (loc. 41), in the Middle East and western Iran (loc. 60, 64). Toads of this clade are separated from subclade B $(2 n-V, 4 n-I I)$ by the central Iranian 
deserts. The clade $2 n-V I$ occurs in the Caucasus and to the northeast in the steppe zone of northwestern Kazakhstan (loc. 61-67), the northern Aral Sea (loc. 80) and further east (loc. 87, 89). MtDNA in the most northern populations in Scandinavia (loc. 8, 11, 12,16) belongs to the same clade, either representing a range disjunction or a connection via Eastern Europe (see 4.4), from which data are missing. Toads from western central Iran (loc. 74, B. v. kermanensis) differ from all remaining members of this clade. A specimen from eastern Syria (loc. 53) yielded a shorter sequence (not in tree) but clearly belongs to this group. Separation of the $2 \mathrm{n}$-VI mitochondrial lineage from European (2n-VII), western Mediterranean (2n-VIII) and all Central Asian groups (A-C) is estimated to have happened between Lower and Middle Pliocene, while its separation from mitochondrial ancestors of African (2n-III, 2n-II) and South Asian clades (3n-I, 3n-II, 2n-I) probably dates back to Middle to Lower Miocene (Table 1). Population growth (Table 2) led us to estimate a minimum expansion age of $2 \mathrm{n}$-VI between 1.2 and 2.4 Mya.

We tentatively refer to these populations as Bufo variabilis (Pallas, 1769), since their range (loc. 8) includes the type locality (Lübeck; Stöck et al., 2001a).

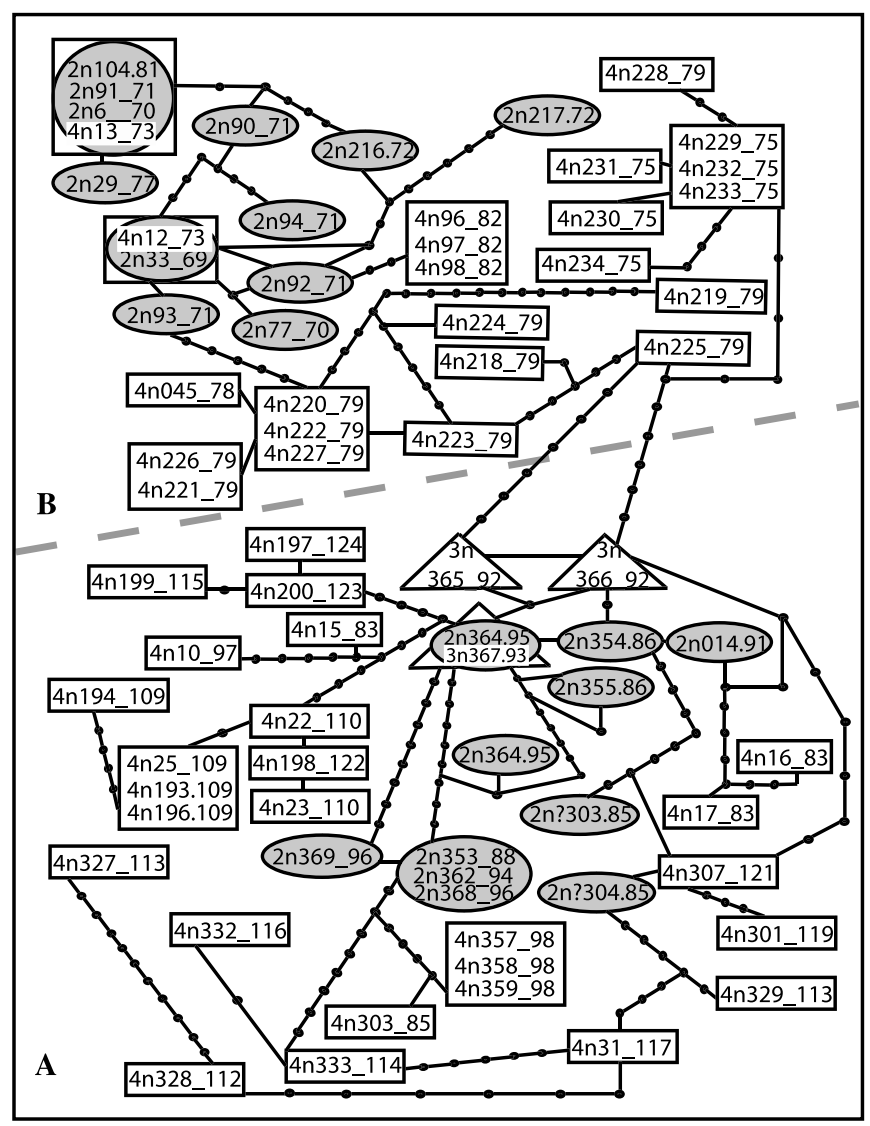

Fig. 4. Parsimony-based haplotype network obtained with the program TCS 1.18 using d-loop sequences of groups A and B of the tree shown in Fig. 3 (left). Gray ellipsoids represent $2 n$, white rectangles $4 \mathrm{n}$ and white triangles indicate $3 \mathrm{n}$ toads. Black dots represent hypothetical haplotypes not sampled. Ploidy levels (e.g. 4n), sample ID (max. three digits, see Appendix A), and locality ID as in (Figs. 1 and 2).

\subsubsection{2 -VII Central, southeastern Europe and northern Asia}

This clade was detected on the Greek mainland, Crete and in northeastern Italy (loc. 13). It apparently dominates most parts of Central Europe (loc. 10, 14, 15, 22-24), occurs in southeastern Europe (loc. 38) and northwest of the Caucasus (loc. 48, 49, 51). In Russia it reaches the northern edge of the range of the subgroup (loc. 50). Possibly disjunct populations were also found in northeastern (loc. 58) and north central Kazakhstan (loc. 90) where the clade meets $2 n-V I$ and $2 n-I V$ toads. The potentially ancestral haplotype inferred from a network analysis (TCS, not shown) was found in the southern Ukraine (loc. 38) and northeastern Italy (loc. 13) and is only one mutational step apart from Greek and Crete haplotypes. Divergencetime estimates of $2 \mathrm{n}$-VII from all other clades are nearly identical to those of the Asia Minor clade (2n-VI), suggesting that a contemporaneous event was responsible for initial vicariance of $2 \mathrm{n}-\mathrm{VI}$ and $2 \mathrm{n}-\mathrm{VII}$. Although moderate growth was detected, is was not significantly different from a zero growth model (Table 2). Clade 2 n-VII represents B. viridis viridis (loc. 22, 23 near the type locality (Vienna).

\subsubsection{2n-VIII Southern Italy and West Mediterranean islands}

MtDNA of $2 \mathrm{n}$ toads from several islands (Corsica, loc. 7; northern Sicily, loc. 20) and the southern Apennine Peninsula (Calabria, loc. 21) clustered together. A museum specimen from Mallorca (loc. 4) provided a shorter readable sequence (not shown in tree) and is assigned to this clade. The small sample size prevented us from application of Fluctuate. This lineage probably diverged from ancestors leading to all European (2nVII), Asia Minor (2n-VI) and Central Asian groups (AC) between the Lower and Middle Pliocene. It may have split from the last common mitochondrial ancestor with the South Asian clades (3n-I, 3n-II, 2n-I) during Lower to Upper Miocene. The name Bufo balearicus Boettger, 1880 is applicable to this taxon (e.g. Garcia-Paris et al., 2004).

\subsubsection{2n-IX Bufo luristanicus}

Three sequences of toads from a single locality (loc. 65) form a well supported clade. A phylogenetic position close to B. viridis $(2 \mathrm{n}-\mathrm{VI})$ and $B$. variabilis $(2 \mathrm{n}-\mathrm{VII})$ is shown by $N D+t R N A \mathrm{~s}$. As compared to the $2 \mathrm{n}$ clades, this taxon differs cytogenetically from them (M. St. unpubl. data).

\subsection{Groups of tetraploid green toads}

Tetraploid toads exclusively originated from a single, mitochondrial lineage in Central Asia (Fig. 3: "Central Asian clade"). We label these groups based mainly on morphology (Stöck, 1997) and chromosomal characters (Stöck et al., 2005): 4n-I, 4n-II and 4n-III. 


\subsubsection{4n-I Eastern Central Asia}

$4 \mathrm{n}$ toads of this group are widely distributed from Uzbekistan (loc. 80) to the west across the Tian Shan (loc. 97-98, 112-113), to the western Altay range (loc. 118121) and the Dzungarian Gobi of Mongolia in the East (loc. 123, 124) and southwards to the eastern Pamirs of northwestern China (loc. 109, 110). Although mitochondrial data are lacking, based on morphology and 4n karyotypes the haplotype group reaches the southeastern most edge of the subgroup's range in the Kun-Lun (northern Tibet). Towards the south, the $>5000 \mathrm{~m}$ high Karakoram range isolates 4 n-I from 3n-II toads (Fig. 2). MtDNA phylogeny of $4 n-I$ is tightly linked to that of $2 n$ IV and 3n-III (group A) as shown by a haplotype network (Fig. 4). Growth values (242; Table 2) yielded minimum population-growth estimates between 0.5 and 0.7 Mya. Tetraploids of group A share uniform Q-banding patterns (Stöck et al., 2005), differ morphometrically from 4n-II toads (Stöck, 1997) and represent B. pewzowi (Stöck et al., 2001a).

\subsubsection{4n-II Western Central Asia}

4ns in northeastern Iran (loc. 75, 78, 79, 82) and western Turkmenistan (loc. 73) show considerable range overlap with $2 n-V$. In group $B$, toads of both ploidy levels $(2 n-V$, $4 n-I I)$ share a mtDNA subclade and sometimes possess identical haplotypes (Figs. 3 and 4). However, we know only a few localities $(81,82)$ with syntopic occurrence of $2 \mathrm{~ns}$ and 4ns. Moderate growth (Table 2) led to minimum expansion age estimates of $4 \mathrm{n}$-II between 0.9 and $1.1 \mathrm{Mya}$, which is older than estimates for other Central Asian toad groups (4n-I, 2n-IV). 4n-I toads of clade B share distinct Qbanding differences in some chromosome quartets (Stöck et al., 2005; our Fig. 3). They represent B. oblongus (details: Stöck et al., 2001a).

\subsubsection{4n-III Bolshoi Balkhan}

$4 \mathrm{n}$ toads from the isolated mountain Bolshoi Balkhan in the western Karakum desert of Turkmenistan (loc. 68) share the karyotype characteristics (Stöck et al., 2005) of $B$. oblongus (4n-II) but are morphologically distinct (Stöck, 1997) and lack a name. They represent the sister taxon of $3 n-I V$, with which they form the well supported clade C, sister group to all Central Asian 2n, 3n and 4n toads in groups A and B (Fig. 3). For 4n-III this is consistent with a long geographical isolation (see Section 4).

\subsection{Groups of triploid green toads}

Triploid toads belong to two very different mitochondrial lineages: one well supported clade comprising two sexually reproducing triploid South Asian high mountain taxa (3n-I, 3n-II), and the others in the "Central Asian clade" (Fig. 3). In the latter, we detected $3 n$ s in groups A (3n-III) and $\mathrm{C}(3 \mathrm{n}-\mathrm{IV})$. The $3 \mathrm{n}-\mathrm{I} / 3 \mathrm{n}-\mathrm{II}$ clade, known from high mountain valleys in Karakoram and Hindukush, has no close diploid or tetraploid relatives.

\subsubsection{3n-I Western Himalayas and eastern Hindukush}

This well supported clade consists of a population of alltriploid males and females from the isolated upper Swat valley (Fig. 2: loc. 100, western Himalayas) and two morphologically similar toads of unknown ploidy from west of Kabul (loc. 99). Fluctuate yielded negative growth values (apparently caused by the inability of the program to deal with genetic uniformity). The divergence time estimates suggest that the mtDNA lineage of 3n-I separated from all other green toad clades (except the South Asian 3n-II and 2n-I) between Middle and Lower Miocene (Table 1), while the lineage leading to $3 n-I$ perhaps diverged during the early Pleistocene from 3n-II but earlier than the Lower Miocene from 2n-I. Based on morphology, Stöck et al. (1999) found 3n-I to be different from 3n-II and the name B. pseudoraddei pseudoraddei to be valid (Stöck et al., 2001a).

\subsubsection{3n-II Karakoram and Chitral}

108 triploid toads (only 26 in tree) from eight populations (Fig. 2: 101-107) in the Karakoram and Hindukush valley of Chitral, inhabiting three different high mountain drainages (Chitral, Gilgit, Hunza river), show almost no variation of d-loop sequences. This indicates a single origin of all 3n-II toads and suggests their recent range expansion to these localities (101-107), although a formal test (Fluctuate) is precluded by the extraordinarily low genetic diversity. The valid name is B. pseudoraddei baturae (Stöck et al., 1999, 2001a). It represents a mitochondrial sister clade of $B$. p. pseudoraddei $(3 \mathrm{n}-\mathrm{I})$, from which it was separated during the Pleistocene (Table 1). In contrast, the lineage leading to $B$. $p$. baturae (3n-II) separated very early (at least Lower Miocene, Table 1) from the mitochondrial lineage of geographically close $B$. latastii (2n-I, western Himalayas, Figs. 1 and 2: loc. 111). Although the minimal absolute distance is below $100 \mathrm{~km}$, mtDNA genotypes of 3n-II are isolated by the Kunyerab Pass $(>4600 \mathrm{~m})$, and therefore are highly differentiated from B. pewzowi (4n-I) in China (loc. 109, 110), which reached the eastern Pamirs (loc. 109) from the north and represents a clade which may have shared a most recent common mitochondrial ancestor with the $3 n-I+3 n-I I$ lineage in the late Miocene (7.3-5.7 Mya). The Central Asian clade includes triploids from a single site in northern Baluchistan (loc. 84) and triploids in zones of range overlap between diploid (2n-IV) and tetraploid (4n-I) in northern central Asia.

\subsubsection{3n-IV Northern Baluchistan}

Eight toads from the type locality of B. zugmayeri (Pakistan, Pishin, loc. 84) have a very similar d-loop sequence. Triploidy based on chromosome preparations of three males and one female suggests the discovery of a second bisexually reproducing all-triploid taxon. Toads from Pishin (loc. 84) are the sister group to 4n-III (loc. 68) and this group $\mathrm{C}$ is sister group to all other Central Asian green toads (groups A + B) of our study. 


\subsubsection{3n-III Eastern Central Asia}

$3 \mathrm{~ns}$ of group B of the Central Asian clade appear to be more closely related to diploids $(2 \mathrm{n}-\mathrm{V})$ than to tetraploids (4n-I), suggesting they may be $3 \mathrm{n} \mathrm{F}_{1}$-hybrids resulting from $2 \mathrm{n}$ female $\times 4 \mathrm{n}$ male crosses (Fig. 4 ).

\subsection{Species excluded as maternal ancestors of polyploid green toads}

D-loop sequences of Bufo arabicus, B. brongersmai, B. luristanicus, B. mauritanicus, B. raddei, B. surdus and $B$. stomaticus differ substantially from that in all polyploid $B$. viridis subgroup taxa. This excludes $B$. stomaticus from being the recent maternal ancestor of $B$. pseudoraddei baturae, with which they are sympatric in the Hindukush (Chitral city, loc. 101). Bufo raddei also did not contribute mitochondrially to allo- or parapatric B. pewzowi (4n-I) in northwestern China and Mongolia (Stöck, 1998b). In addition, B. luristanicus and $B$. surdus, occurring in sympatry with $2 \mathrm{n} B$. variabilis $(2 \mathrm{n}-\mathrm{VI})$ in western and southern Iran, cannot represent the maternal ancestor of western Central Asian B. oblongus (4n-II). Based on their d-loop sequences, B. luristanicus and B. calamita, appear in a polytomy with several other green toads (Fig. 3, left). Nevertheless, $B$. calamita is not closely related to them based on the $N D+t R N A$ s (Fig. 3, right), bioacoustic (Stöck et al., 2001c) and chromosomal differences. Similarly, $N D+t R N A$ s show $B$. luristanicus to be more closely related to European B. v. viridis (2n-VII) and B. variabilis ( $2 \mathrm{n}-\mathrm{VI})$ than to Central Asian 4ns, but further biological data on this rarely collected species are needed.

\section{Discussion}

Our study is a geographically comprehensive genetic analysis of the $B$. viridis subgroup. The subgroup is notable for its broad geographic range, its unsettled taxonomic and nomenclatural history and, especially, for the presence of polyploids, including sexually reproducing triploid lineages. Our main aims were to (i) provide insights into the historical biogeography of the diploid taxa, and (ii) to investigate the matrilineal history of the diverse polyploid lineages. As expected for such a widespread species group, we found extensive geographically structured variation among diploid populations, consistent with other studies of Eurasian phylogeography, which generally show much greater diversity in the south than in the north. We demonstrate that the polyploids $(3 n, 4 n)$ have multiple maternal origins. The Central Asian populations show close mtDNA affinity among diploids (B. turanensis) and tetraploids (B. oblongus, $B$. pewzowi) as well as rare triploids. The sexually reproducing triploids (B. pseudoraddei) have mtDNA that is highly divergent from any sampled diploid population and themselves consist of two divergent clades.

Here, we place the mtDNA results for diploids in the context of the unusually dense fossil record for Eurasian green toads to shed light on geographic origins of the complex and its biogeographic history. We also identify regions with close geographic proximity or overlap of major mtDNA phylogroups that should be the focus of future studies. Regarding the polyploid lineages, we use the mtDNA evidence, together with karyotypic and genetic data to infer origins, biogeographic history and interactions of the polyploid forms. Our results highlight the dynamic history of these lineages, including likely continuing interactions among diploid and polyploid forms.

\subsection{Phylogeographic diversity, origins and historical biogeography of diploid taxa}

Within the $B$. viridis group (B. viridis, B. calamita, B. raddei, B. surdus, B. latastii, B. luristanicus; Borkin, in Frost, 1985 , added $B$. brongersmai), a widely used term coined by Inger (1972), B. viridis itself is nested within multiple, closely related lineages. Stöck et al. (2001a) distinguished these lineages as the $B$. viridis subgroup, based on bioacoustic, cytogenetic and morphological evidence and included $B$. latastii, $B$. oblongus, B. pewzowi, B. viridis viridis, $B$. turanensis, $B$. pseudoraddei pseudoraddei, B. p. baturae and we now add $B$. balearicus, $B$. boulengeri, $B$. variabilis, the unnamed taxon from southeastern Sicily, B. luristanicus, and B. surdus. These taxa form a mitochondrial clade based on $N D+t R N A$ s.

Within this $B$. viridis subgroup, we report evidence (Dloop, $N D+t R N A \mathrm{~s}$ ) that the diploids belong to nine mitochondrial clades. The earliest diverged western Himalayan B. latastii $(2 \mathrm{n}-\mathrm{I})$ and its southern Iranian sister species $B$. surdus represent descendents of an Upper Oligocene/Lower Miocene split (Table 1) from the MRCA with African (2nIII) and all other green toad clades. Isolation by mountain uplifting and speciation of B. latastii in the Kashmir/ Ladakh region might be well linked to the Indian collision with Asia and the rise of the Himalayas.

\subsection{Origin of the Bufo viridis group and subgroup in context with the fossil record}

Provided our divergence times estimates are correct, green toads (lineages $B$. latastii, $B$. surdus) were likely present in Asia before the Afro-Arabian plate first touched Eurasia ( 18 Mya; Rögl, 1998; Tchernov, 1988) since during the entire Oligocene (33.7-23.8 Mya) and early Miocene (23.8 to $\sim 18 \mathrm{Mya}$ ), the Mediterranean was a remnant of the Western Tethys, which connected Indo-Pacific and Atlantic and thus separated Afro-Arabia from Eurasia (Rögl, 1998, 1999).

The presence of bufonids north of this sea barrier before Afro-Arabia and Eurasia collided is also supported by the fossil record, because the oldest Old World bufonid fossils come from Paleocene of northern France (Rage, 2003) and middle Oligocene of Kazakhstan (Chikvadze, 1985). Therefore, (1) arrival of bufonids in Eurasia based on fossils and our divergence time estimates seem to reject a "pure Miocene out of Africa hypothesis" for Eurasian toads. One alternative hypothesis (2) of a trans-Beringian invasion of Eurasian toads from the Nearctic (e.g. Blair, 1972; Borkin, 1999: Oligocene) was rejected by Pauly et al. (2004), who 
reviewed previous hypotheses on the origin of Nearctic toads but found no close relationship of a single $B$. viridis to recent Nearctic species. However, (3) Pramuk (2006), using molecular and morphological evidence, finds that Eurasian Bufo lineages form a basal sister clade to a New World radiation. Thus, Miocene bufonids may have reached Europe [as well as the Nearctic?] from Asia (Sanchiz, 1997; Rage and Rocek, 2003). This latter hypothesis is further supported by the fact that all living $B$. viridis group taxa occur in Eurasia, and two (B. calamita, B. raddei) diverged even earlier, before the $B$. viridis subgroup arose (Fig. 3). All B. viridis group and subgroup species occur in temperate Palearctic climate (Borkin, 1999). During the estimated early Miocene split of the subgroup, similar to recent climatic conditions probably prevailed (van der Made, 1999), suggesting adaptation of the B. viridis group to temperate environments throughout its history. The northwest African B. brongersmai can no longer be considered close to the subgroup since karyotype (Herrero et al., 1993), advertisement calls (Bogaerts, 2001, call recording in litt.) and larval morphology (Grillitsch et al., 1989), as well as our $N D+t R N A$-phylogeny (Fig. 3), reject close relationships.

The surprisingly rich fossil record for B. viridis or "Bufo aff. viridis" (for overview: Sanchiz, 1998; Kordikova, 1998; Rocek and Rage, 2000; Rage and Rocek, 2003; Böhme, 2003) also shows the oldest known remains to be found in Eurasia (Fig. 1) rather than in Africa (although the latter fossil record is poorly known, Rocek and Rage, 2000). The oldest fossils (Fig. 1) of B. aff. viridis (Claessens, 1997; Rocek and Rage, 2000) come from the Lower Miocene of northern Anatolia (18-20.5 Mya, Böhme, M. in litt.), the Lower Miocene of southeastern France (Rage and Rocek, 2003), central Iberia (Rage and Rocek, 2003; doubtful: Sanchiz, 1998), and southern Germany (17.5-18 Mya; Böhme, 2003). B. calamita is also known from the Lower Miocene of Spain (Rage and Rocek, 2003). Pre-Pleistocene B. viridis fossils are lacking from Central Asia, but B. raddei is reported from the Upper Miocene to the Lower Pleistocene of northeastern Kazakhstan (Chikvadze, 1985; Kordikova, 1998; Sanchiz, 1998). In North Africa, the oldest known $B$. viridis fossils are only from the Pliocene of Morocco (Bailon, 2000), much younger then the oldest from Eurasia. Taken together, all early fossils were found in Eurasia and are either older than or contemporaneous to the collision of Afro-Arabia and Eurasia (18-19 Mya).

\subsection{Miocene and Pliocene splits}

Our data show the mitochondrial lineages of the B. viridis subgroup to have diversified since the Oligocene/Early Miocene (Table 1), with five major extant lineages [B. surdus, B. latastii (2n-I), B. boulengeri (2n-III), unnamed Sicilian taxon (2n-II), B. pseudoraddei (3n-I, 3n-II)] likely to have diverged during the Oligocene/Miocene ( $>23.8$ 5.3 Mya). All of these occur in the southern part of the range. During the Pliocene (5.3-1.8 Mya), four major hap- lotype groups [B. balearicus (2n-VIII), B. variabilis $(2 \mathrm{n}-\mathrm{VI})$, B. viridis (2n-VII), the Central Asian clade] evolved.

\subsection{Late Quaternary recolonization of higher latitudes}

The B. viridis subgroup (clades $2 \mathrm{n}$-VI, 2n-VII, 2n-VIII) reflects biogeographic patterns which were shown for many Palearctic animal and plant species (reviews: Taberlet et al., 1998; Hewitt, 2004; Petit et al., 2003). This includes "extensive extinction and recolonization in higher latitudes and altitudinal shifts and complex refugia nearer the tropics" (Hewitt, 2004). The "southern peninsulas of [...] Italy and the Balkans-Greece, along with the Caspian/Caucasus region [represent] refugia, and taxonomic and genetic diversity [is found] in and among these regions" (Hewitt, 2004). During maximal Pleistocene glaciations, Central European green toads were probably extinct or forced to retract to southern refugia. Therefore, European Miocene fossils (see above) and extant haplotype groups (2n-VI, 2n-VII) cannot be linked. By Late Pleistocene (Early Weichselian), B. viridis had returned to Central Europe (fossils: Mlynarski et al., 1978; Böhme, 1991).

Our study shows potential refugia of clade $2 n-V I I$ on the Balkan Peninsula (loc. 13, 30), perhaps extended to the southern Ukrainian steppe (loc. 38), and a Post-Pleistocene northwestern range expansion to its current western range limit at the Rhine. This scenario fits the shallow structure of $2 \mathrm{n}$-VII and its star-like radiation (TCS, not shown) from inferred ancestral haplotypes at refugial localities (loc. 38, 13). The most divergent haplotypes (eastern loc. 58, 90 of $2 \mathrm{n}$-VII) may represent haplotypes at a different glacial refugium or isolates from a previous glacial cycle.

The occurrence of a second northern European clade $(2 n-V I)$ in Sweden, Denmark and northern Germany (loc. $8,11,12,16)$ underlines mobility of green toads and shows the dynamics of postglacial colonization. We propose two alternative hypotheses: (i) Clade $2 n-V I$ spread during a previous interglacial cycle and reached the western range in the upper Rhine valley, and colonized Scandinavia to the northeast after the last glacial maximum (LGM). The Rhine/Rhone area is a well-known "major refugium" (Hewitt, 2004). (ii) Alternatively, toads reached southeastern Scandinavia, perhaps via an eastern Carpathian corridor, and/or crossed the Baltic Sea. Under (i) clade 2n-VI is expected in southwestern Germany. If, in contrast, hypothesis (ii) applies, we predict its presence in northern Poland/ northeastern Germany.

\subsection{Clade boundaries and possible interactions of diploids}

We have outlined major dimensions of clade distribution, but identification of exact clade boundaries and contact zones is a challenge for future research. Studying postglacial colonization will likely reveal several Central and/or east European contact zones (e.g. in Germany) between $2 \mathrm{n}$-VI and 2n-VII, which also meet between Abrau Peninsula (loc. 48, 49, 51) and the Caucasus (loc. 
52). High allozyme variation (Karakousis and Kyriakopoulou-Sklavounou, 1995) on the Greek mainland (loc. $25,27-29)$ may represent both clades or may stem from their hybridization. Serum albumins of toads (called ' $B$. viridis arabicus', Flindt and Hemmer, 1968) from southeastern Turkey (Adana, i.e. 2n-VI, close to loc. 42-44) differ from Central-European B. viridis (our 2n-VII). In northwestern Kazakhstan (loc. 58, 61-63, 66, 67), where only $2 \mathrm{~ns}$ are reported (Dujsebayeva et al., 2003), both clades (2n-VI, $2 n-V I I)$ are found in close proximity and in north central Kazakhstan (loc. 85-90) these clades meet a third (2n-IV) in a region where Stipa grass steppe turns into Artemisia semi-desert. While most data suggest geographic sorting (not in Greece 2n-VII, 2n-VI; unclear for northern Kazakhstan), future research should address whether and where these two (or three) mitochondrial clades are broadly sympatric (as e.g. in B. gargarizans, $\mathrm{Fu}$ et al., 2005) or even admixed and might represent cases of non-polyploid reticulate evolution.

Hybridization of small-sized 2n-VI and large-sized 2nIV toads in northern Kazakhstan is suggested by a few individuals that exhibit reciprocal haplotypes and phenotypes. The Asia Minor (2n-VI) and the African (2n-III) clades, which may have separated as long as 10 Mya (Table 1), may contact on Sinai, "a major barrier for amphibian dispersal between Africa and Asia" (Borkin, 1999). While this statement is primarily supported by our data, Werner (1982, cit. in Borkin, 1999) listed B. viridis as "the only amphibian [occurring at] the northeastern corner of Sinai as in the Negev" desert. Maxson (1981), using immunology, which also revealed differences between $B$. viridis from Tunisia (our 2n-III), Yugoslavia (2n-VI or 2n-VII) and Israel (2nVI), differentiated $B$. viridis from northeastern Sinai (El Arish, but also Nahal Kzib, northern Israel) from most other Israeli green toads, raising the possibility that these southwestern populations are of African origin. Size differences (Nevo, 1972) could have the same explanation. For many terrestrial African and Eurasian vertebrates Sinai was an intercontinental crossroad (Tchernov, 1988) until the Pleistocene.

\subsection{Origin, interaction and dynamics of lineages containing polyploids}

\subsubsection{Pliocene origin of and Pleistocene expansions in the Central Asian clade}

In the $N D+t R N A$ s tree (Fig. 3, right), the three Central Asian representatives B. oblongus (4n-II), B. turanensis (2n$\mathrm{V})$ and $B$. pewzowi (4n-I) form a well supported sister clade of the B. v. viridis $(2 \mathrm{n}-\mathrm{VII}) / B$. variabilis $(2 \mathrm{n}-\mathrm{VI}) / B$. luristanicus clade. Divergence time estimates (Table 1) based on dloop sequences suggest that the Central Asian clade diverged from geographically neighboring Asia Minor (2nVI) populations in the Pliocene (4.4-3.1 Mya, Table 1), contemporaneous with global cooling and drying, which led to the spread of grasslands, potentially in favor of green toads, a steppe species.
Strong signatures of population growth (4n-I, 4n-II) suggest that mtDNA-lineages of polyploids expanded in the Pleistocene (Table 2), a previously proposed time of $4 n$ formation (Mezhzherin and Pisanets, 1995), when further cooling and increasing aridity may have resulted in sudden selective advantage of the polyploids, which currently dominate the climatically extreme high mountains and continental cold winter eastern deserts of Central Asia (Stöck et al., 2001b), where they show high temperature tolerance ( -30 to $45^{\circ} \mathrm{C}$; Kuzmin, 1999) and inhabit elevations $<3700 \mathrm{~m}$ a.s.l. (Stöck et al., 2001b). Island patterns of Pleistocene lowland permafrost in Central Asia, as low as $900 \mathrm{~m}$ a.s.l. (Aubekerov and Gorbunov, 1999), potentially left space for scattered Pleistocene refugia of cold-tolerant toads. By implication, distinct lowland desert gecko species (Teratoscincus), evolved during the Tertiary northwest and southeast of the Tian Shan (Macey et al., 1999), also must have had Pleistocene refugia in the region.

\subsubsection{Hypothetical matrilineal origin of Bufo pewzowi ( $4 n$ - I) and Bufo oblongus (4n-II)}

Bufo turanensis $(2 \mathrm{n}-\mathrm{V})$ exhibits Q-bands in both copies of chromosome 6, while B. oblongus (4n-II) has a karyotype containing two Q-positive and two Q-negative chromosomes 6, suggesting their allopolyploid (hybrid) origin (Stöck et al., 2005). Some Q-positive $2 \mathrm{n}$ toads may have been one of the ancestral forms of these $4 \mathrm{n}$ toads. Because the common mitochondrial haplotype in group B of the Central Asian Clade is found in the Q-banding-positive $2 \mathrm{~ns}$, they likely represent the maternal ancestors of western Central Asian 4n-II (B. oblongus). If this is correct, then the other, Q-negative paternal ancestor is unknown or may no longer exist.

In group A, B. pewzowi (4n-I) have four Q-banding positive chromosomes 6, suggestive of autopolyploidy. Some Q-positive 2ns must be their ancestors, and the extant B. turanensis ( $2 \mathrm{n}-\mathrm{IV})$ are candidates.

\subsubsection{Possible interactions between diploids and tetraploids within the Central Asian clade}

In the Central Asian clade, diploid B. turanensis (2nIV, $2 n-V$ ), which are differentiated by calls (Castellano et al., 1998; Stöck, 1998a), morphology (Stöck, 1997) and allozymes (Mezhzherin and Pisanets, 1995) from their tetraploid counterparts (4n-I, 4n-II), show close mtDNA affinities to either B. pewzowi (4n-I, in group A) or $B$. oblongus (4n-II, in group B). A haplotype network (Fig. 4) reflects these similar situations in groups A and B with most $4 \mathrm{~ns}$ being at least two mutational steps from $2 \mathrm{~ns}$. Pairwise $F_{S T}$ values between $4 \mathrm{n}-\mathrm{II}$ and $2 \mathrm{n}-\mathrm{V}(0.2)$ and $4 \mathrm{n}-\mathrm{I}$ and $2 \mathrm{n}-\mathrm{IV}$ ( 0.38 ; Table) suggest some separation between gene pools of diploids and tetraploids of both groups (A and B). However, two toads of $4 \mathrm{n}-\mathrm{II}$ (B. oblongus) from Danata (loc. 73, Turkmenistan) have identical mtDNAhaplotypes with $2 \mathrm{n}-\mathrm{V}$ from several northeastern Iranian localities (loc. 69-71, 81), implying multiple origins and retained ancestral polymorphism or some degree of recent 
Table 3

Population pairwise $F_{\mathrm{ST}}$ values in groups of the Central Asian clade

\begin{tabular}{lllll}
\hline & $2 n-V$ & $4 n-I I$ & $2 n-I V$ & $3 n-I I I$ \\
\hline 2n-V (Western Central Asia) & 0 & & & \\
4n-II (Western Central Asia) & 0.20191 & 0 & & \\
2n-IV (Eastern Central Asia) & 0.75292 & 0.57400 & 0 & \\
3n-III (Eastern Central Asia) & 0.77040 & 0.56410 & 0.02613 (ns) & 0 \\
4n-I (Eastern Central Asia) & 0.48036 & 0.38231 & 0.34358 & 0.35531 \\
\hline
\end{tabular}

hybridization. If $2 \mathrm{n}-\mathrm{V}$ and $4 \mathrm{n}-\mathrm{II}$ toads rarely hybridize, "mismatings" may be limited by different calls (Castellano et al., 1998; Stöck, 1998a). Triploid females, reported from one locality (73; Pisanets, 1978), may be fertile, as are other $3 \mathrm{n}$ toads (Stöck et al., 2002) or waterfrogs (e.g. Günther, 1990). Alternatively, rare unreduced $2 \mathrm{n}$ gametes of $2 \mathrm{n}$ toads (e.g. Bogart, 1972) and their fusion with normal $2 \mathrm{n}$ gametes of $4 \mathrm{~ns}$ (Stöck et al., 2002) may lead to hybrid meiotic $4 \mathrm{n}$ offspring carrying nuclear and mitochondrial genes from the $2 \mathrm{n}-\mathrm{V}$ into the $4 \mathrm{n}-\mathrm{II}$ gene pool. Stöck et al. (2005) found some 4n-II karyotypes with one or three instead of two homologous Q-positive chromosomes 6, consistent with introgression of Q-positive chromosomes from the $2 \mathrm{n}-\mathrm{V}$ into the $4 \mathrm{n}-\mathrm{II}$ gene pool, possibly restricted to single unreduced eggs of $2 n-V$.

Similarly, all unequivocally $2 \mathrm{n}-\mathrm{IV}$ toads (B. turanensis) are at least four mutational steps apart from the closest $4 \mathrm{n}$ I individuals (B. pewzowi), while rare triploids (3n-III from Northern Kyrgyzstan, loc. 92, 93) share the mtDNA with some 2n-IV (or are only one mutational step apart, Fig. 4) and therefore might be $\mathrm{F}_{1}$ hybrids ( $2 \mathrm{n}-\mathrm{IV}$ female $\times 4 \mathrm{n}-\mathrm{I}$ male). Indeed, the pairwise $F_{S T}$ value (Table 3 ) found to be $\sim 0.35$ between $4 \mathrm{n}-\mathrm{I}$ and $2 \mathrm{n}$-IV or $3 \mathrm{n}$-III, was only 0.026 between $2 n-I V$ and $3 n-I I I$, implying a separation of gene pools of $2 n-I V$ and $4 n-I$ but almost no separation of $2 n-I V$ and $3 \mathrm{n}$-III within group A. Rare $3 \mathrm{n}$-III, which comprise $\sim 5 \%$ of some regional populations, may consist of males only (Borkin et al., 2001; pers. observation). Even if $3 \mathrm{n}$ hybrids are all-male or hypothetical $3 \mathrm{n}$ females are sterile, mtDNA introgression might still result (as proposed for clade B) from single unreduced eggs of 2n-IV females, which are fertilized by $4 \mathrm{n}$ (or $3 \mathrm{n}$ ) males and contribute to introgression of $2 \mathrm{n}-\mathrm{IV} \mathrm{mtDNA}$ in the $4 \mathrm{n}-\mathrm{I}$ gene pool.

These intriguing questions of possible gene exchange and/or continuing reticulation between $2 \mathrm{n}$ and $4 \mathrm{n}$ toads in a system of "porous" gene pools in diverging taxa, which may occasionally exchange genetic material via rare triploids, require further analyses with rapidly evolving nuclear markers (e.g. microsatellites) from a close contact zone of $2 \mathrm{n}$ and $4 \mathrm{n}$ toads.

\subsubsection{Distinctiveness of tetraploid toads from Bolshoi Balkhan (4n-III)}

Distinctive d-loops in green toads from Bolshoi Balkhan (loc. 68) match the separate phylogeographic position of agamids (Macey et al., 1998a,b, 2000) from that island mountain, which also exhibits high plant endemism (Proskuriakova, 1971). This evidence supports a biogeographic separation of Bolshoi Balkhan from Kopet Dagh and eastern Iran (Khorasan). Caspian Sea transgressions and temporary western drainage ("Uzboi") of the Amur-Darya kept the region isolated (Atamuradov, 1994). Nevertheless, the close mitochondrial relationship of $4 n-I I I$ to $3 n-I V$ toads (B. zugmayeri), a potentially second sexually reproducing triploid taxon from northern Baluchistan, is currently unexplained but suggests former range connections across the non-sampled southwest of Afghanistan.

\subsubsection{Matrilineal origin of $3 n$ Bufo pseudoraddei in High Asia}

Morphologically distinguishable $B$. pseudoraddei pseudoraddei (3n-I) and B. p. baturae (3n-II) share a common maternal ancestor, which is only distantly related to green toads (2n, 3n 4n) of the Central Asian clade (Fig. 3) and to geographically proximate $B$. latastii $(2 \mathrm{n}-\mathrm{I})$. No living recent $2 \mathrm{n}$ or $4 \mathrm{n}$ maternal ancestor of the $3 \mathrm{n} B$. p. pseudoradde $i$ and $B$. p. baturae is known. Although their mtDNA genotype also differs substantially from all other mitochondrial clades, this is not necessarily evidence for their great evolutionary age (see below).

\subsubsection{Glaciation in Karakoram, Hindukush and western}

Himalayas caused speciation and late invasion of green toads

We sampled B. p. pseudoraddei (3n-I) at two sites in the lower Kabul and Swat river drainages (Fig. 2: loc. 99, 100), and B. p. baturae (3n-II) in Hunza, Gilgit, and Chitral valleys (loc. 101-108). Both high mountain taxa split off in early Pleistocene (Table 1), suggesting that glaciation forced them into different refugia. Since both taxa are 3n, triploidy might have evolved before their separation (1.61.3 Mya). Triploidy, however, may be younger than the monophyletic $3 n-I+3 n-I I$ mitochondrial lineage, if the mitochondrial lineage diverged and evolved earlier in an unknown $2 \mathrm{n}$ ancestor.

Current Himalaya and Transhimalaya (the Karakoram represents its western end) contain the highest non-polar concentration of glaciers. However, changing monsoon influence caused Quaternary glaciations to be dynamic and asynchronous to northern cycles. Pleistocene Hunza valley (Fig. 2: loc. 106-108) was so heavily glaciated (Owen et al., 2000a) that extant B. p. baturae (3n-II) could not have spent the ice age at its current sites (2000-3000 m a.s.l.) but must have invaded from southern refugia. During the northern last glacial maximum (LGM), Himalayan glaciations were limited (Ref. in Benn and Owen, 2002). Indeed, Upper Hunza (loc. 106-108) first became ice free postglacially (Gulkin I stage) during the last glacial maximum (Owen et al., 2000a). Owen et al. (2000b) concluded that all of late Pleistocene Chitral (loc. 101, 102) was filled with a huge glacier system above $1300 \mathrm{~m}$ (Drosh stage), which would have made continued existence of 3n-II toads in Chitral impossible. Glaciation here (upper Mastuj valley: 102) lasted at least until early Holocene. The Shandur Pass (loc. 103; $3720 \mathrm{~m}$ a.s.l.) was icecovered as recently as middle or late Holocene (Owen et al., $2000 \mathrm{~b}$ ). Therefore, $3 \mathrm{n}$-II toads must have crossed this pass 
(loc. 103) later. Far downstream of Chitral, towards the other clade (3n-I: loc. 99, 100), modern climate is too hot for temperate-adapted green toads, and consequently genetically uniform 3n-II must have invaded Chitral (loc. 101, 102) from the East (loc. 105, 104), crossing Shandur (loc. 103). This implies a Pleistocene refugium of $3 \mathrm{n}$-II in the Himalayan Indus valley (S of loc. 105), which was ice-free south of $\sim 35^{\circ}$ $\mathrm{N}$ in late Pleistocene (Kamp and Haserodt, 2004). B. p. pseudoraddei (3n-I) from Paghman (loc. 99) and Swat (loc. 100 ), forming two subclades of 3n-I, supposedly reached these sites from southern refugia in the Kabul river drainage during Holocene warming and may no longer be in genetic contact. Their occurrence close (loc. 99) to the Salang Pass ( $3880 \mathrm{~m}$, slightly above the maximum elevation of green toad records) in the Hindukush raises questions whether this lineage could surmount the range to the North and would then be found in northern Afghanistan and western Tajikistan. A range limit of $B$. p. baturae (3n-II) exists between their easternmost record (loc. 105) and the westernmost record (loc. $111)$ of $B$. latastii $(2 \mathrm{n}-\mathrm{I})$ in the rock gorge of the Indus river (Stöck et al., 2001b), where both taxa occur allopatrically. However, Baig (1998) reported sympatry of $B$. latastii and B. pseudoraddei (3n-I or 3n-II?) in the "Neelam (= Jhelum) valley" of Azad Kashmir (eastern Pakistan).

\section{Conclusions: phylogenetic and evolutionary implications of polyploidy in the Bufo viridis subgroup}

We have provided evidence for ancient splits of mitochondrial lineages at different time depths. Several clades meet each other geographically and their interactions, especially the extant of hybridization and/or polyploidization, offer appealing research opportunities. Our mtDNA analyses show that polyploidy in the B. viridis subgroup evolved several times. Cytogenetic data (Stöck et al., 2005) suggest at least two origins of 4ns (B. oblongus, 4n-I; B. pewzowi, 4n-II). Unique to the present data is the demonstration that the mitochondrial ancestor contributing to morphologically distinctive (Stöck et al., 1999, 2001a) triploid toads from Karakoram and Hindukush (B. p. pseudoraddei, 3n-I; B. p. baturae, $3 \mathrm{n}-\mathrm{II}$ ) is different from the lineage leading to different groups of Central Asian tetraploids. This fascinating genomic diversity is further highlighted by the apparent discovery (further tests ongoing) of a new potentially sexually reproducing $3 \mathrm{n}$ taxon (B. zugmayeri, 3n-IV) within the Central Asian clade and especially by the probable continuing interactions of parapatric diploid and tetraploid toads. In their contact zones, diploid, triploid and tetraploid genotypes interact (and likely co-evolve), and show that vertebrate evolution can not only tolerate but readily incur major changes in genome size and composition, which signals genomic plasticity. Given the relatively rare occurrence of polyploidy in Bufo (e.g. Tandy et al., 1985; King, 1990; Vences and Wake, in press), this also suggests that certain propertiesof the $B$. viridis genome may be especially suitable for the appearance of polyploidy, a hypothesis that deserves further investigation (e.g. by artificial polyploidization experiments). Bufo asmarae (Tandy et al., 1982), a tetraploid species from the B. regularis group with $4 n=40$ chromosomes, is an evolutionary parallel of possibly hybrid origin (Tandy et al., 1985) in which comparative research with molecular methods would be of great interest.

Multiple origins of polyploids in green toads may be the rule rather than the exception, as in several other polyploid vertebrate groups (see introduction; Cunha et al., 2004; Ptacek et al., 1994; Evans et al., 2004, 2005; Tsigenopoulos et al., 2002). The role of hybridization and reticulation in animal evolution is still debated and restricted by our currently limited access to genomes of non-model organisms. Easily observable quantitative differences in diploid/polyploid complexes make us aware of the fluidity and plasticity of genomes and this "view of the tip of the ice berg" could mean that introgression, fusion and hybridization are not only tolerable but may be a major component of animal evolution (cf. Morjan and Rieseberg, 2004; Mavárez et al., 2006; Patterson et al., 2006).

\section{Acknowledgments}

This work was supported by a research fellowship (Sto 493/1-1) from the Deutsche Forschungsgemeinschaft (DFG) to M. Stöck and the University of California, Berkeley (Craig Moritz and David Wake).

The following people helped with collecting and/or sending specimens or tissue samples: C. Andrén (Alvhem), M. Auer (Dresden), A. Basheeva (Karaganda), W. Böhme (Bonn), S. Bogaerts (Nijmegen), D. Buckley (Berkeley), M. Chirikova (Almaty), L. Choleva (Libechov), T. Dieterich (Astana), R. Dressel (Dresden), U. Fritz (Dresden), K. Fog (Vekso), F. Glaw (Munich), E. Gnidenko (Almaty), R. Günther (Berlin), W.-R. Grosse (Halle), C. Herden (Lauenburg), C. Klütsch (Bonn), L. Kratochvil (Prague), S. Kuzmin (Moscow), N. Lutzmann (Zurich), C. Miaud (Le Bourget du Lac), M. Ogielska (Wrozlaw), Zh. Oralov (Astana), J. Martens (Mainz), J.F. Parham (Berkeley), E. Recuero (Madrid), U. Scheidt (Erfurt), J.F. Schmidtler (Munich), H. Veith (Halle), J. Vörös (Budapest), S. Voitel (Eisleben), T. Woeltjes (The Netherlands). D.K. Lamatsch (Brussels) and C. Steinlein (Würzburg) helped with ploidy determination by flow cytometry. M. Stöck is grateful for references or information from B. Clarke (London), A. Ohler (Paris), J. Pramuk (Provo), C. Muster (Leipzig), L. Owen (Cincinnati), E. Roitberg (Rostock), Y.L. Werner (Jerusalem); for references and discussion on fossil B. viridis: M. Böhme (Munich); for correspondence on Mediterranean paleogeography: F. Rögl (Vienna); for veterinary services: F. Mutschmann (Berlin), and for discussion, the choice of the mitochondrial marker and various support: M. Schartl (Würzburg). M. Stöck wishes to thank many colleagues in the MVZ (Berkeley) who helped with some methodological approaches, especially N.M. Belfiore, B. Slikas, R. Bingham, M. Brandley, C. Conroy, T. Devitt, M. Fujita, J. Kapoor, A. Leaché, J.B. MacKenzie, I. Martínez-Solano and J. McGuire. R. Hijmans provided valuable cartographic support. 


\begin{tabular}{|c|c|c|c|c|c|c|c|c|c|c|}
\hline Map & Voucher (if available) & GenBank Acc. No. & Taxon & Locality & Ploidy & $N$ & $\begin{array}{l}\text { Sample-ID } \\
\text { (see Figs. } 3 \text { and } 4 \text { ) }\end{array}$ & LAT & LONG & $\begin{array}{l}\text { ELEVATI ON } \\
\text { (if known) }\end{array}$ \\
\hline 1 & - & DQ629730 & B. boulengeri & Morocco, AitBaha, E. Recuero leg. & $2 \mathrm{n}$ & 1 & 371 & 30.130 & -9.080 & \\
\hline 2 & MTD45286 & DQ629718 & B. boulengeri & Morocco, High Atlas, D. Frynta leg. & $2 n$ & 1 & 112 & 32.427 & -5.156 & \\
\hline 3 & $\mathrm{CUP} \backslash \mathrm{AMPH} \backslash \mathrm{MOR} \backslash 01$ & DQ629704 & B. boulengeri & Morocco, High Atlas, D. Frynta leg. & $2 n$ & 1 & 179 & 33.427 & -5.150 & 1438 \\
\hline 4 & ZFMK 37856 & - & B. balearicus & $\begin{array}{l}\text { Spain,Balearic islands, Mallorca, Caps } \\
\text { Andraixs, C.A.Raehmel leg.1982 }\end{array}$ & $2 \mathrm{n}$ & 1 & 160 & 39.500 & 3.000 & \\
\hline 5 & ZFMK49652 & DQ629720 & B. boulengeri & Algeria, Ghardaia, W. Bischoff, U. Joger leg. & $2 n$ & 1 & 163 & 32.483 & 3.667 & \\
\hline 6 & MVZ 235680 & DQ629721, DQ629602 & B. boulengeri & $\begin{array}{l}\text { Tunisia, Nefta oasis, Tawzar (= T0zeur) } \\
\text { Governorate, T. Papenfuss } 6 \text { Feb } 2002 \text { leg. }\end{array}$ & $2 \mathrm{n}$ & 1 & 166 & 33.917 & 3.133 & 45 \\
\hline 7 & ZSM 6/2004 & DQ629731, DQ629598 & B. balearicus & $\begin{array}{l}\text { France, S-Corsica, near Bonifacio, } 19 \text { June } \\
\text { 2002, F. Glaw, K. Schmidt. leg. }\end{array}$ & $2 \mathrm{n}$ & 1 & 175 & 41.383 & 9.150 & \\
\hline 8 & - & DQ629645 & B. variabilis & $\begin{array}{l}\text { Germany, Schleswig-Holstein, Woltersdorf } \\
\text { near Lübeck, C. Herden leg. }\end{array}$ & $2 \mathrm{n}$ & 1 & 310 & 53.583 & 10.633 & \\
\hline 9 & ZFMK 14704 & DQ629719 & B. boulengeri & $\begin{array}{l}\text { Tunesia, Djerba island, Kiehlmann leg. } \\
1974\end{array}$ & $2 \mathrm{n}$ & 1 & 165 & 33.800 & 10.900 & \\
\hline 10 & ZSM 5/2004 & DQ629671 & $\begin{array}{l}\text { Natural cross } B \text {. calamita } \\
\text { male } \mathrm{x} B \text {. viridis female }\end{array}$ & Germany, Fürstenfeldbruck, E. Andrä leg. & $2 \mathrm{n}$ & 1 & Hyb-IV & 48.180 & 11.250 & \\
\hline 11 & - & DQ629670 & B. variabilis & Denmark, NW Lolland, K. Fog leg. & $2 \mathrm{n}$ & 1 & 296 & 54.900 & 11.250 & \\
\hline 12 & MVZ 247648 (tissue) & DQ629632 & B. variabilis & $\begin{array}{l}\text { Denmark, Falster, a few km S Nykøbing } \\
\text { Falster, K. Fog leg. }\end{array}$ & $2 n$ & 1 & 295 & 54.750 & 11.800 & \\
\hline 13 & - & DQ629687 & B. viridis & $\begin{array}{l}\text { Italy, Padua, University of Würzburg } 1995 \\
\text { leg. }\end{array}$ & $2 \mathrm{n}$ & 1 & 21 & 45.417 & 11.883 & \\
\hline 14 & MVZ 241555 & DQ629674 & B. viridis & $\begin{array}{l}\text { Germany, Halle (Saale), Martin-Luther- } \\
\text { University Halle-Wittenberg, Botanical } \\
\text { Garden, W. Grosse and M. Stöck leg. }\end{array}$ & $2 \mathrm{n}$ & 1 & 171 & 51.833 & 12.000 & \\
\hline 15 & NME 974/02 & DQ629672, DQ629673 & B. viridis & $\begin{array}{l}\text { Germany, Thuringia, Falkenhain, opencast, } \\
\text { mining "Phönix Nord" leg. A. Nöllert }\end{array}$ & $2 \mathrm{n}$ & 2 & 190,191 & 51.417 & 12.883 & \\
\hline 16 & $\begin{array}{l}\text { MVZ 244350, 244354, } \\
244355 \text { (tadpoles) }\end{array}$ & $\begin{array}{l}\text { DQ629659, } \\
\text { DQ629662, } \\
\text { DQ629663, } \\
\text { DQ629664, } \\
\text { DQ629665, DQ629666 }\end{array}$ & B. variabilis & Sweden, Malmö, Limhamn, C. Andren leg. & $2 \mathrm{n}$ & 7 & $241,242,266$ & 55.583 & 12.900 & \\
\hline 17 & - & DQ629717 & B. boulengeri & $\begin{array}{l}\text { Libya, Al' Fiayi, Sabah Province, D. Frynta } \\
\text { leg. }\end{array}$ & $2 \mathrm{n}$ & 1 & 140 & 26.533 & 13.317 & \\
\hline 18 & - & $\begin{array}{l}\text { DQ629705, } \\
\text { DQ629706, DQ629707 }\end{array}$ & B. boulengeri & Libya, Gabroon Lake, D. Frynta leg. & $2 n$ & 2 & $139,107,114$ & 26.800 & 13.533 & \\
\hline 19 & - & $\begin{array}{l}\text { DQ629726, } \\
\text { DQ629727, } \\
\text { DQ629728, } \\
\text { DQ629729, DQ629608 }\end{array}$ & Unnamed & $\begin{array}{l}\text { Italy, Sicily, E of Lentini, near mouth of San } \\
\text { Leonardo River, } 500 \mathrm{~m} \text { from coast inland }\end{array}$ & $2 \mathrm{n}$ & 4 & $323,324,325,326$ & 37.333 & 15.067 & \\
\hline 20 & NME 912/01 & DQ629732 & B. balearicus & $\begin{array}{l}\text { Italy, Sicily, N Francavilla di Sicilia, stream } \\
\text { valley, T. Zavianni, A. Nöllert leg.. } 16 \text { April } \\
1995\end{array}$ & $2 n$ & 1 & 188 & 37.900 & 15.133 & \\
\hline 21 & NME 913/01 & DQ629733 & B. balearicus & $\begin{array}{l}\text { Italy, W coast, Calabria, Paola, A. Nöllert } \\
\text { leg., } 17 \text { April } 1995\end{array}$ & $2 n$ & 1 & 189 & 39.350 & 16.033 & \\
\hline 22 & ZFMK 65102 & DQ629661 & B. viridis & $\begin{array}{l}\text { Austria, moutainous country above } \\
\text { Eisenstadt }\end{array}$ & $2 \mathrm{n}$ & 1 & 144 & 47.850 & 16.516 & \\
\hline
\end{tabular}




\begin{tabular}{|c|c|c|c|c|c|c|c|c|c|c|}
\hline Map & Voucher (if available) & GenBank Acc. No. & Taxon & Locality & Ploidy & $N$ & $\begin{array}{l}\text { Sample-ID } \\
\text { (see Figs. } 3 \text { and } 4 \text { ) }\end{array}$ & LAT & LONG & $\begin{array}{l}\text { ELEVATI ON } \\
\text { (if known) }\end{array}$ \\
\hline 23 & MVZ 164718 & DQ629686, DQ629606 & B. viridis & $\begin{array}{l}\text { Austria, MVZ frozen tissue collection (FC } \\
\text { 13312), } 3.2 \mathrm{~km} \text { E Podersdorf Buraenland, } \\
\text { Austria: R. D. Sage leg. }\end{array}$ & $2 \mathrm{n}$ & 1 & 168 & 47.850 & 16.833 & \\
\hline 24 & HNHM2004.94.2 & DQ629678 & B. viridis & $\begin{array}{l}\text { Hungary, Central Hungary, Orgovany, May } \\
\text { 2004, L. Forro leg. }\end{array}$ & $2 \mathrm{n}$ & 1 & 265 & 46.750 & 19.467 & \\
\hline 25 & ZFMK 62479 & DQ629722 & B. variabilis & $\begin{array}{l}\text { Greece, Epirus, S Igoumenitsa, Patraia, W. } \\
\text { Böhme leg. } 1996\end{array}$ & $2 \mathrm{n}$ & 1 & 149 & 39.500 & 20.266 & \\
\hline 26 & MTD 45036,45281 & $\begin{array}{l}\text { DQ629710, } \\
\text { DQ629711, DQ629712 }\end{array}$ & B. boulengeri & $\begin{array}{l}\text { Libya, Shahhat (Ancient Cyrene), Binghazi } \\
\text { Province, D. Frynta leg. }\end{array}$ & $2 \mathrm{n}$ & 3 & $109,131,138$ & 32.817 & 21.867 & \\
\hline 27 & - & DQ629630 & B. variabilis & Greece, Peloponnes, J. Plötner leg. & $2 n$ & 1 & 99 & 37.516 & 22.367 & \\
\hline 28 & NME 901/01 & DQ629675 & B. viridis & $\begin{array}{l}\text { Greece, Peloponnes, Kióna, E-Bank } \\
\text { Stymphalian Lake, leg. A. Nöllert, } 10 \text { April } \\
1996\end{array}$ & $2 \mathrm{n}$ & 1 & 187 & 37.850 & 22.450 & \\
\hline 29 & NME 900/01 & DQ629654 & B. viridis & & $2 \mathrm{n}$ & 1 & 186 & 38.133 & 23.000 & \\
\hline 30 & $\begin{array}{l}\text { NME A } 1037 / 03 \\
(2 \mathrm{nd}+3 \mathrm{rd} \text { indivi }\end{array}$ & DQ629655, DQ629656 & B. viridis & Greece, Crete, Omalos, U. Scheidt leg. & $2 \mathrm{n}$ & & 133,134 & 35.333 & 23.900 & \\
\hline 31 & - & DQ629657, DQ629658 & B. viridis & $\begin{array}{l}\text { Greece, Crete, Aradena village, } 19 \text { April } \\
\text { 2003, leg. U. Scheidt }\end{array}$ & $2 n$ & 2 & 135,136 & 35.200 & 24.083 & \\
\hline 32 & MTD 45275,45276 & DQ629667, DQ629668 & B. viridis & Greece, Crete, via J. Plötner & $2 \mathrm{n}$ & 2 & 100,101 & 35.417 & 24.750 & \\
\hline 33 & MTD 45280, 45282 & DQ629714, DQ629715 & B. boulengeri & Egypt, Matrouh, via E. J. Bentley & $2 \mathrm{n}$ & 2 & 108,110 & 30.000 & 28.000 & \\
\hline 34 & MVZ 230206, 230207 & DQ629621, DQ629624 & B. variabilis & $\begin{array}{l}\text { Turkey, Cicekli Köyü, } 7 \text { km E (by road) Ula } \\
\text { Mugla Prov., T. Papenfuss leg. }\end{array}$ & $2 \mathrm{n}$ & 2 & 236,237 & 37.066 & 28.500 & \\
\hline 35 & ZFMK 77600, 77601 & DQ629708, DQ629709 & B. boulengeri & $\begin{array}{l}\text { Egypt, Oasis Dakhla (Dakhilah, Al Wahat } \\
\text { ad), N. Lutzmann leg. }\end{array}$ & $2 \mathrm{n}$ & 2 & 146,147 & 25.553 & 28.948 & \\
\hline 36 & MVZ 230208 & DQ629623, DQ629600 & B. variabilis & $\begin{array}{l}\text { Turkey, Osman Gazi, Bursa, Bursa Prov., T. } \\
\text { Papenfuss leg. }\end{array}$ & & & 238 & 40.167 & 29.083 & \\
\hline 37 & MTD 45277 & DQ629713 & B. boulengeri & Egypt, 70 km S Alexandria, via J. Bentley & $2 \mathrm{n}$ & 1 & 105 & 31.000 & 30.000 & \\
\hline 38 & MTD42716,42717 & DQ629684, DQ629685 & B. viridis & $\begin{array}{l}\text { Ukraina, Cherson Oblast, Golija Pristan, U. } \\
\text { Fritz leg. }\end{array}$ & $2 n$ & 2 & 184,185 & 46.516 & 30.516 & \\
\hline 39 & ZFMK 50909 & DQ629716 & B. boulengeri & $\begin{array}{l}\text { Egypt, Alexandria, El Menoufia (via U. } \\
\text { Sinsch), } 1989\end{array}$ & $2 n$ & 1 & 159 & 30.500 & 31.000 & \\
\hline 40 & CS96V:4 & DQ629625 & B. variabilis & $\begin{array}{l}\text { Turkey, Central Turkey, S. Doganhisar, } \\
\text { Prov. Konya, } 1650 \text { m, } 31 \text { May 1996, Central } \\
\text { Turkev. J.F Schmidtler leg. }\end{array}$ & $2 \mathrm{n}$ & 1 & 253 & 38.150 & 31.683 & \\
\hline 41 & CS73V:1 & DQ629636 & B. variabilis & $\begin{array}{l}\text { Greece, Cyprus, Lefka, } 16 \text { April 1973, J.F. } \\
\text { Schmidtler leg. }\end{array}$ & $2 \mathrm{n}$ & 1 & 259 & 35.117 & 32.850 & \\
\hline 42 & CS98V:1 & DQ629651 & & $\begin{array}{l}\text { Turkey, Tepeköy, NW Mersin, } 5 \text { April 1998, } \\
\text { J F. Schmidtler leg. }\end{array}$ & $2 \mathrm{n}$ & 1 & 257 & 36.217 & 33.566 & 1250 \\
\hline 43 & MVZ 247506 (tissue) & DQ629648 & B. variabilis & $\begin{array}{l}\text { Turkey, Kizakalesi Korykos, Kizkalesi, } \\
\text { Silifke } 19 \text { July 2004, L. Choleva leg. }\end{array}$ & $2 n$ & 2 & 289 & 36.360 & 33.930 & \\
\hline 44 & CS96V:1 & DQ629626 & B. variabilis & $\begin{array}{l}\text { Turkey, Limonlu, } 50 \text { km W Mersin, } 300 \text { m; } 9 \\
\text { April 1996, J.F. Schmidtler leg. }\end{array}$ & $2 n$ & 1 & 250 & 36.566 & 34.250 & \\
\hline 45 & CS96V 3 & DQ629627 & B. variabilis & $\begin{array}{l}\text { Turkey,Güzelyurt, Pr. Akhisar, } 1550 \text { m; } 29 \\
\text { May 1996, J F. Schmidtler leg. }\end{array}$ & $2 n$ & 1 & 252 & 38.283 & 34.383 & \\
\hline 46 & NME A 1039/03 & DQ629724 & B. variabilis & Syria, Doura Europus, D. Frynta leg. & $2 n$ & 1 & 111 & 33.483 & 36.000 & \\
\hline
\end{tabular}


$49 \quad$ ZMB 57384

$50 \quad$ MVZ 218679

51 ZMB 64802, 64803

54 MVZ 247493, 247505 (tissue), 247495-247503 (tadpoles)

55 MVZ 244345, 244346

56 MVZ 247494, 24704 (tissue)

$57 \quad-$

$58-$

59 CAS 182891

$60 \quad$ MTD 45284

$61-$

$62-$

$63-$

64 NME A 1038/03

$65 \quad$ MTKDD 43943

$66-$

$67-$

$68-$
DQ629679, $\quad$ B. viridis DQ629680, DQ629681

DQ629682 B. viridis

DQ629669 B. viridis

DQ629676, DQ629677 B. viridis

DQ629683 B. viridis

- $\quad$ B. variabilis

DQ629631, Bariabilis

DQ629633, DQ629649

DQ629628, DQ629629 B. variabilis

DQ629634, B. variabilis DQ629635, DQ629650

$\begin{array}{ll}\text { DQ629701 } & \text { B. variabilis }\end{array}$

DQ629698 B. viridis

DQ629653 Bariabilis

DQ629622 B. variabilis

DQ629637, DQ629642 B. variabilis

DQ629639

B. variabilis

DQ629640

B. variabilis

DQ629723

B. variabilis

DQ629614,

B. luristanicu.

DQ629615,

DQ629616, DQ629610

DQ629638

B. variabilis

DQ629641

B. variabilis

DQ629768, DQ629769 Unnamed rre, Cedrus forest, $2300 \mathrm{~m}$ a.s.

Bischoff. J.F., H. Schmidtler. in den Bosch

leg.

Russia, NW Caucasus, Dzhemete near $\quad$ 2n $\quad 3 \quad 204,205,206 \quad 44.947 \quad 37.306$

Anapa, T. Kirschey leg.

$\begin{array}{llllll}\text { Russia, NW of Caucacasus, Suko near } & \text { 2n } & 1 & 203 & 44.883 & 37.317\end{array}$

Anapa T.Kirschev leg.

$\begin{array}{lllllll}\text { Tula region, Tula oblast, Russia, leg. } & 2 \mathrm{n} & 1 & 271 & 54.117 & 37.367\end{array}$

Russia, Abrau Peninsula, NW Caucasus, T. $\quad 2 n \quad 2 \quad 211,212 \quad 44.69737 .596$

Kirschey leg.

Russia, NW Caucasus, Goverdovski near $\quad 2 n \quad \begin{array}{llll}1 & 209 & 44.608 & 40.106\end{array}$

Maikop, T. Kirschey leg.

Syria, Dayr az Zawr, Hotel Al Waha, left $\quad$ 2n $\quad 1 \quad 157 \quad 35.33340 .150$

Euphrat bank 1994, W. Bischoff leg.

Turkey, Nemrut Dagh and E of Nemrut, L. 2n

$3281,284,288$

$38.660 \quad 42300$

Choleva leg.

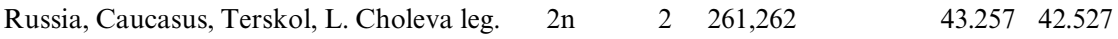

Turkey, Karahan-Kars lli, Van Golu (N), $\quad$ 2n $\quad 3 \quad 282,286,287 \quad 39.00043 .760$

$\begin{array}{llllll}\text { Karahan Koyu, } 4 \text { July 2004, L. Choleva leg. } & & & & & \\ \text { Iran, Kara Kelisa or Kare Kilise villiage, } & \text { 2n } & 1 & 95 & 38.950 & 44.467\end{array}$

Urda, E. Gnidenko leg.

Kazakhstan, Beket-Ordinsky Rayon, village $\quad 2 n-1337$

Urda, E. Gnidenko leg.

$\begin{array}{lllll}\text { Russia, Dagestan Autonomous Republic, } & 2 n & 1 & 202 & 42.967 \quad 47.500\end{array}$

Sary Kum Sand Dunes, at Kumtorkala

Railroad Station, T. Papenfuss/R. Macey

leg.

Iran, Choqa Zanbil, Elamite zikkurat, $\quad$ 2n $\quad 1 \quad 115$

$32.014 \quad 48.529 \quad 45$

$49.213 \quad 50.307$

Kazakhstan, Djangalinsky Rayon, village $\quad 2 n$

Djangala, E. Gnidenko leg.

Kazakhstan, Akjainskiy rayon, Kalmykovo, 2n

E. Gnidenko leg.

Kazakhstan, Syrymski Rayon, village $\quad$ 2n $\quad 1338$

Djambeity, E. Gnidenko leg.

Iran, Central; Iran, Qasr-e-Sásán, D. Frynta $\quad 2 n \quad 1113$

leg. 2000

Iran, Posht Chenar, D. Frynta les.

$2 n$

$358,176,177$

Kazakhstan, W $80 \mathrm{~km}$ E of Uralsk city, $\quad$ 2n $\quad 1 \quad 334$

Berezka river, M. Chirikova leg.

Kazakhstan, Karatobinsky Rayon, village 2n

Karatobe, E. Gnidenko leg.

Turkmenistan, Bolshoi Balkhan, M. Stöck 4n

1994 leg.

$49.031 \quad 51.825$

$50.254 \quad 52.605$

$29.195 \quad 53.231$

$29.200 \quad 53.333 \quad 1690$

$51.000 \quad 53.354$

$49.692 \quad 53.549$

$39.717 \quad 54.483 \quad 500$

(continued on next page) 
Appendix A (continued)

\begin{tabular}{|c|c|c|c|c|c|c|c|c|c|c|}
\hline Map & Voucher (if available) & GenBank Acc. No. & Taxon & Locality & Ploidy & $N$ & $\begin{array}{l}\text { Sample-ID } \\
\text { (see Figs. } 3 \text { and } 4 \text { ) }\end{array}$ & LAT & LONG & $\begin{array}{l}\text { ELEVATI ON } \\
\text { (if known) }\end{array}$ \\
\hline 69 & - & DQ629690 & B. cf. turanensis & $\begin{array}{l}\text { Iran, NE,N-slope Elburz-Range, near } \\
\text { Gorgan, M.Stöck } 1994 \text { leg. }\end{array}$ & $2 \mathrm{n}$ & 1 & 33 & 37.000 & 54.500 & \\
\hline 70 & - & $\begin{array}{l}\text { DQ629690, } \\
\text { DQ629688, DQ629689 }\end{array}$ & B. cf. turanensis & $\begin{array}{l}\text { Iran, NE, } 50 \text { km NE Gonbad-e-Kavus, M. } \\
\text { Stöke leg. }\end{array}$ & $2 \mathrm{n}$ & 1 & 6.77 & 37.633 & 55.483 & 250 \\
\hline 71 & MVZ 249177, 249178 & $\begin{array}{l}\text { DQ629691, } \\
\text { DQ629692, } \\
\text { DQ629693, } \\
\text { DQ629694, DQ629695 }\end{array}$ & B. cf. turanensis & $\begin{array}{l}\text { Iran, Marrave Tappe, Mazandaran } \\
\text { province, Westernmost foothills ofKopet } \\
\text { Dagh, D. Frynta leg. }\end{array}$ & $2 n$ & 5 & $90-94$ & 37.733 & 55.901 & 665 \\
\hline 72 & $\begin{array}{l}\text { MVZ 245917, CAS } \\
228604\end{array}$ & $\begin{array}{l}\text { DQ629702, } \\
\text { DQ629703, DQ629605 }\end{array}$ & B. cf. turanensis & $\begin{array}{l}\text { Iran, Delbar Field Station, Touran } \\
\text { Protected Area, T Papenfuss, O. Mozafari, } \\
\text { H. Fahimi,S. Shafiei, K. Kamali } 2005 \text { leg. }\end{array}$ & $2 \mathrm{n}$ & 2 & 216,217 & 35.967 & 56.068 & 1196 \\
\hline 73 & MTD 39400, 39401 & DQ629766, DQ629767 & B. oblongus danatensis & Turkmenistan, Danata, M. Stöck 1994 leg. & $4 n$ & 2 & 12,13 & 38.617 & 56.633 & \\
\hline 74 & MTD 40730,40731 & DQ629619, DQ629620 & B. viridis kermanensis & $\begin{array}{l}\text { Iran, Kerman, southern Central Iran, M. } \\
\text { Stöck } 1998 \text { leg. }\end{array}$ & $2 n$ & 2 & 43,44 & 30.300 & 57.083 & 1860 \\
\hline 75 & $\begin{array}{l}\text { CAS 228820-228823, } \\
\text { MVZ 245911-245914 }\end{array}$ & $\begin{array}{l}\text { DQ629744, } \\
\text { DQ629745, } \\
\text { DQ629746, } \\
\text { DQ629747, } \\
\text { DQ629748, } \\
\text { DQ629749, DQ629750 }\end{array}$ & B. oblongus & $\begin{array}{l}\text { Iran, Kharve, } 23 \mathrm{~km} \mathrm{~N} \text { Tabas, Yazd Prov., } \\
\text { T. Papenfuss } 2005 \text { leg. }\end{array}$ & $4 \mathrm{n}$ & 7 & 228 to 234 & 33.641 & 57.162 & \\
\hline 76 & - & DQ629696 & B. turanensis & $\begin{array}{l}\text { Iran, Bik, Central Kopet Dagh, Khorasan } \\
\text { province, D. Frynta leg. }\end{array}$ & $2 \mathrm{n}$ & 1 & 87 & 37.606 & 57.944 & 1467 \\
\hline 77 & MTD 44397 & DQ629699 & B. turanensis & $\begin{array}{l}\text { Turkmenistan, Ashgabad, M. Stöck, A. } \\
\text { Bischoff, K. Holländer } 1994 \text { leg. }\end{array}$ & $2 n$ & 1 & 29 & 37.950 & 58.383 & \\
\hline 78 & MTKDD41347 & DQ629778, DQ629779 & B. oblongus & Iran, Birjand M. Stöck 1998 leg. & $4 n$ & 2 & 45,46 & 32.550 & 59.167 & 1500 \\
\hline 79 & $\begin{array}{l}\text { CAS 228604, 228690- } \\
228694,228699, \mathrm{MVZ} \\
245904-24907\end{array}$ & $\begin{array}{l}\text { DQ629734, } \\
\text { DQ629735, } \\
\text { DQ629736, } \\
\text { DQ629737, } \\
\text { DQ629738, } \\
\text { DQ629739, } \\
\text { DQ629740, } \\
\text { DQ629741, } \\
\text { DQ629742, DQ629743 }\end{array}$ & B. oblongus & $\begin{array}{l}\text { Iran, Khorasan Province, Bande-dare } \\
\text { Spring(Dam), 4 km (by. road) S of } \\
\text { Jaanbaazaan Square, Birjand, J.F. Parham, } \\
\text { T. Papenfuss, O. Mozafari, H. Fahimi,S. } \\
\text { Shafiei leg. } 2005\end{array}$ & $4 n$ & 10 & $218-227$ & 32.822 & 59.218 & 1655 \\
\hline 80 & $\begin{array}{l}\text { MVZ 248372, } \\
\text { 248373(tissue) }\end{array}$ & DQ629646, DQ629647 & B. variabilis & $\begin{array}{l}\text { Kazakhstan, Aral Sea, NW coast of } \\
\text { Shevchenko Gulf, T.Duisebaveva leg. }\end{array}$ & $2 \mathrm{n} ?$ & 2 & 305,306 & 46.578 & 59.925 & 55 \\
\hline 81 & - & DQ629700 & B. turanensis & $\begin{array}{l}\text { Iran, Bazangan, Khorasan province, D. } \\
\text { Frynta leg. }\end{array}$ & $2 n ? 2 n$ & 1 & 104 & 36.280 & 60.548 & 750 \\
\hline 82 & $\begin{array}{l}\text { MVZ 241548, 1241549, } \\
248374\end{array}$ & $\begin{array}{l}\text { DQ629751, } \\
\text { DQ629752, } \\
\text { DQ629753, DQ629601 }\end{array}$ & B. oblongus & $\begin{array}{l}\text { Iran, Bazangan, Khorasan province, D. } \\
\text { Frynta leg. }\end{array}$ & $4 n$ & 3 & $96,97,98$ & 36.280 & 60.548 & 750 \\
\hline 83 & $\begin{array}{l}\text { MTD 39405, 39406, } \\
40010\end{array}$ & $\begin{array}{l}\text { DQ629763, } \\
\text { DQ629764, DQ629765 }\end{array}$ & B. pewzowi & $\begin{array}{l}\text { Uzbekistan, Nuratau range, M. Stöck } 1996 \\
\text { leg. }\end{array}$ & $4 n$ & 4 & $15,16,17$ & 40.583 & 36.500 & $900-1600$ \\
\hline 84 & $\begin{array}{l}\text { MVZ 250382-250385, } \\
250779\end{array}$ & $\begin{array}{l}\text { DQ629770, } \\
\text { DQ629771, } \\
\text { DQ629772, } \\
\text { DQ629773, } \\
\text { DQ629774, }\end{array}$ & B. zugmayeri & $\begin{array}{l}\text { Pakistan, Pishin, T. Papenfuss leg. April } \\
2005\end{array}$ & $3 n$ & 3 & $\begin{array}{l}343,344,345,346 \\
347,348,349,350\end{array}$ & 30.580 & 67.000 & \\
\hline
\end{tabular}


DQ629775,

DQ629776, DQ629777

$85 \quad$ MVZ

248370(tissue),248371

(juv.)

86 MVZ 249171, 249172

87 ZMB 60364

MVZ 249170

89 MVZ 249168, 249169

$90 \quad$ MVZ 249173

$91-$

92 MVZ 249163, 259164

$93-$

$94 \quad$ MVZ 249174

$95-$

$96-$

97 MTD 40012

98 MVZ 249159-249162

99 MVZ 237418, 237419

100 ZSM 106/1998, MTD 44393

$101 \quad$ MVZ 241553

$102-$

$103 \quad$ MVZ 241554
DQ629791, DQ629792

B. cf. turanensis

DQ629801, DQ629802 B. viridis

DQ629652

B. cf. variabilis

DQ629800

Supposed hybrid $B$ variabilis/turanensis

DQ629643, DQ629644 B. cf. variabilis

DQ629697

B. viridis

DQ629780

B. turanensis

DQ629812, DQ629813 Supposed hybrids $B$.

DQ629814 pewzowilB. turanensis Supposed hybrid $B$. pewzowilB. turanensis

DQ629809 B. pewzowi

DQ629810, DQ629811 B. pewzowi

DQ629807, DQ629808 B. turanensis

DQ629783, DQ629784 B. pewzowi

DQ629803,

B. pewzowi

DQ629804,

DQ629805, DQ629806

DQ629846, DQ629847 B. pseudoraddei

DQ629843, B. pseudoraddei

DQ629844, DQ629845 pseudoraddei

DQ629815, DQ629816 B. pseudoraddei baturae

DQ629837, $\quad$ B. pseudoraddei baturae

DQ629838, DQ629839

DQ629817 B. pseudoraddeibaturae B. pseudoraddei
Kazakhstan, environs of Taldy-Say village, $\quad 2 n ? \quad 2 \quad 303,304$

$48.224 \quad 67.052$

504

T.Dujsebayeva leg.

Kazakhstan,40 km NW of Kyzyldzhar, M. 2n Stöck leg. 23 May 2005

Kazakhstan, Tengiz Lake, $12 \mathrm{~km} \mathrm{~W}$ of

Abaya village. T. Dieterich

Kazakhstan, $45 \mathrm{~km} \mathrm{~S}$ of Kurgaldhinskiy, $\quad 2 \mathrm{n} \quad 1 \quad 353$

Kulanulpes-River, M. Stöck leg. 22 May

Kazakhstan, SW of Astana, M. Stöck leg. 22 2n May 2005

Kazakhstan, Karaganda, $\mathrm{N}$ of railway near $2 \mathrm{n}$

city center, M. Stöck leg. 24 May 2005

Kyrgyzstan, Bishkek, Botan. Garden, M. 2 n

Stöck 1993 leg.

Kyrgyzstan, S of Bishkek, loc. Point 4, M. 3n

Stöck leg. 15 May 2005

Kyrgyzstan, S of Bishkek, loc. Point 6, M.

Stöck leg. 15 May 2005

Kyrgyzstan, S of Bishkek, loc. Point 1,M. 2n

Stöck leg. 15 May 2005

Kyrgyzstan, S of Bishkek, loc. Point 3, M. 2n

Stöck leg. 15 May 2005

Kyrgyzstan, $\mathrm{N}$ of Bishkek, Ala-Archinskoye 2n

Vodochranilishche, M. Stöck leg. 18 May

2005

Kyrgyzstan, Issyk-Kul, M. Stöck leg. 1995 4n

Kazakhstan, Almaty, entrance Gorki park, 4n

M. Stöck leg. 27 May 2005

Afghanistan, Kabul Prov., stream ca. 4 km 3n

above Paghman, T. Papenfuss leg.

Pakistan, Swat-Valley, Kulalai, W-

Himalaya, Pakistan, M. Stöck, M. Möller leg. 1996

Pakistan, Chitral, Hinkukush, NW-Frontier 3n Prov., M. Stöck, R. Dressel leg.

Pakistan, NW-Frontier Prov., Booni, M. Stöck, R. Dressel 2000 leg.

Pakistan, Shandur-Pass, Hindukush, NW- $\quad 3 n$ Frontier Prov., M. Stöck, R. Dressel 2000

leg.
2303,304

$48.542 \quad 69.283$

504

1143

351,352

$51.125 \quad 71.267$

1356

$49.792 \quad 73.092$

14

2365,366

$42.900 \quad 74.600$

$42.690 \quad 74.630$

1367

1362

$42.720 \quad 74.660$

$42.780 \quad 74.660$

2363,364

$42.790 \quad 74.760$

2368,369

4330075000

210,11

$42.467 \quad 76.200$

$4 \quad 357,358,359,360 \quad 43.250 \quad 76.956$

$2 \quad 297,298$

$34.610 \quad 68.920 \quad 2608$

$7 \quad 24,125,137$

$35.317 \quad 72.600 \quad 1750$

1171,72

$\begin{array}{lll}35.883 & 71.783 \quad 1480\end{array}$

$3 \mathrm{~B} 1,2,3$

$8 \quad 73$

$\begin{array}{lll}36.333 & 72.333 \quad 1900\end{array}$

$\begin{array}{lll}36.066 & 72.517 \quad 3720\end{array}$ 
Appendix A (continued)

\begin{tabular}{|c|c|c|c|c|c|c|c|c|c|c|}
\hline Map & Voucher (if available) & GenBank Acc. No. & Taxon & Locality & Ploidy & $N$ & $\begin{array}{l}\text { Sample-ID } \\
\text { (see Figs. } 3 \text { and } 4 \text { ) }\end{array}$ & LAT & LONG & $\begin{array}{l}\text { ELEVATI ON } \\
\text { (if known) }\end{array}$ \\
\hline$\overline{104}$ & - & DQ629818, DQ629819 & B. pseudoraddei baturae & $\begin{array}{l}\text { Pakistan, Gupis, Karakoram, Northern } \\
\text { Areas Prov., M. Stöck, R. Dressel } 2000 \text { leg. }\end{array}$ & $3 n$ & 7 & 60,61 & 36.233 & 73.450 & 2160 \\
\hline 105 & ZSM 111/1998, 112/1998 & $\begin{array}{l}\text { DQ629820, } \\
\text { DQ629821, } \\
\text { DQ629822, } \\
\text { DQ629823, } \\
\text { DQ629825, } \\
\text { DQ629826, DQ629827 }\end{array}$ & B. pseudoraddei baturae & $\begin{array}{l}\text { Pakistan, Gilgit, Karakoram, Northern } \\
\text { Areas Prov., M. Stöck, R. Dressel } 2000 \text { leg. }\end{array}$ & $3 n$ & 8 & $\begin{array}{l}32,35-37,48-50 \\
74\end{array}$ & 35.900 & 74.400 & 1550 \\
\hline 106 & - & DQ629842 & B. pseudoraddei baturae & $\begin{array}{l}\text { Pakistan, Northern Areas, Hunza-Valley, } \\
\text { river bank, Karimabad near Ganesh, M. } \\
\text { Stöck, R. Dressel } 2000 \text { leg. }\end{array}$ & $3 n$ & 8 & 130 & 36.300 & 74.683 & 2060 \\
\hline 107 & $\begin{array}{l}\text { MVZ 241552, ZMB } \\
58769\end{array}$ & $\begin{array}{l}\text { DQ629828, } \\
\text { DQ629829, } \\
\text { DQ629830, } \\
\text { DQ629831, } \\
\text { DQ629832, } \\
\text { DQ629833, } \\
\text { DQ629834, } \\
\text { DQ629835, } \\
\text { DQ629836, DQ629604 }\end{array}$ & B. pseudoraddei baturae & $\begin{array}{l}\text { Pakistan, Pasu, Karakoram, Northern } \\
\text { Areas Prov., M. Stöck, H. Veith,R. Dressel } \\
1997 \text { and } 2000 \text { leg. }\end{array}$ & $3 n$ & 59 & $\begin{array}{l}39,40,41,62,65- \\
68,117\end{array}$ & 36.500 & 74.867 & 2700 \\
\hline 108 & $\begin{array}{l}\text { ZSM 101/1998, ZSM } \\
102 / 1998\end{array}$ & DQ629840, DQ629841 & B. pseudoraddei baturae & $\begin{array}{l}\text { Pakistan, Sust, Karakoram, Northern Areas } \\
\text { Prov., M. Stöck, M. Möllerleg. }\end{array}$ & $3 n$ & 2 & 27,28 & 36.767 & 74.833 & 2950 \\
\hline 109 & $\begin{array}{l}\text { ZSM 110/1998, CAS } \\
197007-197010\end{array}$ & $\begin{array}{l}\text { DQ629756, } \\
\text { DQ629757, } \\
\text { DQ629758, } \\
\text { DQ629759, } \\
\text { DQ629760, DQ629603 }\end{array}$ & B. pewzowi taxkorensis & $\begin{array}{l}\text { China, NW-China, Taxkurgan, E-Pamir, M. } \\
\text { Stöck, T. Papenfuss, J.R. Macey leg. }\end{array}$ & $4 n$ & 5 & $25,193-196$ & 37.783 & 75.233 & 3350 \\
\hline 110 & ZSM 107/1998, 108/1998 & DQ629781, DQ629782 & B. pewzowi & $\begin{array}{l}\text { China, Kashgar, Xinjiang, China, M. Stöck } \\
1996 \text { leg. }\end{array}$ & $4 n$ & 2 & 22,23 & 39.483 & 76.033 & 1350 \\
\hline 111 & ZMB 62722, ZMB 62723 & $\begin{array}{l}\text { DQ629848, } \\
\text { DQ629849, } \\
\text { DQ629850, } \\
\text { DQ629851, } \\
\text { DQ629852, } \\
\text { DQ629853, } \\
\text { DQ629855, } \\
\text { DQ629856, } \\
\text { DQ629857, } \\
\text { DQ629858, } \\
\text { DQ629859, } \\
\text { DQ629860, } \\
\text { DQ629861,DQ629862, } \\
\text { DQ629863, DQ629599 }\end{array}$ & B. latastii & $\begin{array}{l}\text { Pakistan, Northern Areas (Baltistan), } \\
\text { Himalaya, Satpara river and Satpara lake } \\
\text { SW of Skardu, M. Stöck, R. Dressel } 2000 \\
\text { leg. }\end{array}$ & $2 n$ & 12 & $\begin{array}{l}78,79,81,127 \\
128,164\end{array}$ & 35.283 & 75.617 & 2300 \\
\hline 112 & - & DQ629796 & B. pewzowi & $\begin{array}{l}\text { Kazakhstan, SE, near Kokpak, M. } \\
\text { Chirikova leg. }\end{array}$ & $4 n$ & 1 & 328 & 42.810 & 79.872 & 1843 \\
\hline
\end{tabular}




\section{$117 \quad$ ZSM 109}

$118-$

$119-$

$120-$

$121-$

122 CAS167832, 167834

$123 \quad$ CAS171676

CAS171053

Laboratory crosses and outgroup taxa

$$
\begin{aligned}
& - \\
& -
\end{aligned}
$$

MVZ 186039

DQ629786

B. pewzowi

DQ629798

B. pewzowi

DQ629785

B. pewzowi

DQ629789

B. pewzowi

DQ629790

B. pewzowi

DQ629794

B. pewzowi

DQ629793

B. pewzowi

DQ629761, DQ629788 B. pewzowi

DQ629787 B. pewzowi

DQ629762

B. pewzowi

-

Laboratory cross

DQ629755

Laboratory cross

DQ629854

Laboratory cross

DQ629617, DQ629607 B. calamita
Kazakhstan, SE, Shalkudysu river, M.

Chirikova leg.

Kazakhstan, E Tarbagatai Tebiske river, M. 4n

Chirikova leg.

China Xinjiang Uygur Auto. Regionálli $4 \mathrm{n}$

Kazak Auto. Prefecture Tacheng Dist.

along Liu Su stream at Liu Su Gou, $29 \mathrm{~km} \mathrm{E}$

of Miao'ergou Autonomous Region, B.

Macey, T. Papenfuss leg.

Kazakhstan, E. Akzhar village, M. $\quad$ 4n $\quad 1 \quad 332 \quad 47.640 \quad 83.795 \quad 62$

Chirikova leg.

China, E-Tien-Shan, NW-China, Xinjiang,

M. Stöck 1996 leg.

Kazakhstan, S-Bukombay Mountains, $\quad 4 n \quad 1 \quad 300$

(northern boundary of Zaissan Depression),

T. Dujsebayeva leg.

Kazakhstan, S foothills of Altai range, $\quad$ 4n $\quad \begin{array}{lll}1 & 301\end{array}$

Prirechnoye village, T. Dujsebajeva leg.

Kazakhstan, Altai range, environs of

Terekti (formerly Alexeevka) village. T.

Duisebaieva leg.

Kazakhstan, Altai, Pakhmanovskiye

Klyuchi $\mathrm{N}$ boundaries of S Altay range. $\mathrm{T}$.

Dujsebayeva leg.

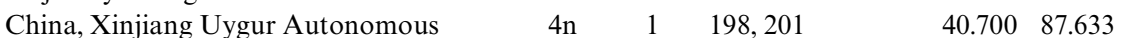

Region, Bayingolin Mongol Macey, T.

Papenfuss leg. 1988

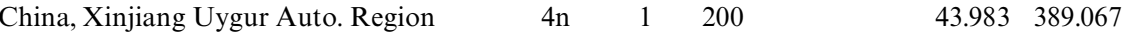

Changji Hui Auto. Prefecture, canyon above

Dayou, $8.1 \mathrm{~km} \mathrm{~S}$ of Dayou, Tien Mountain,

R. Macey and T.J. Papenfuss leg. 1988

China, Xinjiang Uygur Autonomous

$\begin{array}{lll}4 \mathrm{n} & 1 & 301\end{array}$

$48.450 \quad 85.733$

Region, sand dunes, Hami-Barkol Kazak

Autonomous County (town), J.R. Macey, T.

Papenfuss leg.

$43.233 \quad 84.667 \quad 2145$

$48.250 \quad 84.800$

Mother: B. pewzowi, Kyrgyzstan, lssyk-Kul $\quad 3 n ! \quad 1 \quad 19 \mathrm{C}$ $4 n=44)$, father: B. cf. oblongus,

Turkmenistan. Bolshoi Balkhan $(4 \mathrm{n}=44)$

Mother: B. pewzowi, Kyrgyzstan, Issyk-Kul 4n $\quad 1 \quad$ 20C

$(4 n=44)$, father: $B$. oblongus,

Turkmenistan, Danata $(4 n=44)$

$\begin{array}{llll}\text { Mother: B. latastii, Pakistan, Skardu } & 3 n & 1 & \text { Cr243 }\end{array}$

$(2 n=22) \times$ father $B$. pseudoraddei baturae

Pakistan. Karakoram. Pasu $(3 n=33)$

Spain, Cadiz Prov., Andalusia, 3.1 km S

2n $\quad 1 \quad 169$

Benalup de Sidonia on road to Veier de La

Frontera, J.A. Visnaw leg.
$36.333 \quad 5.817$ 


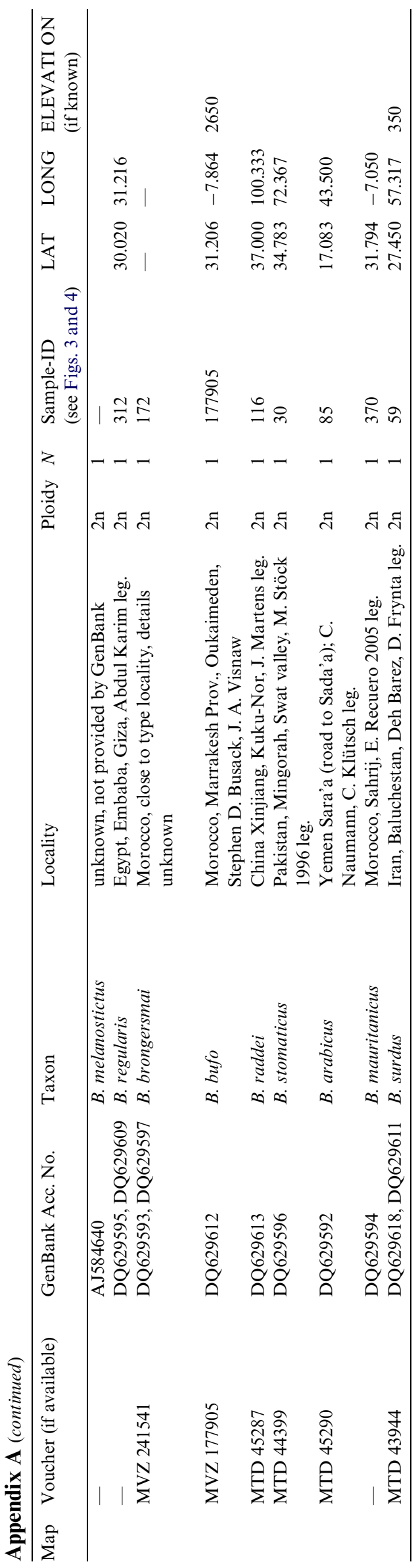

\section{References}

Alves, J.M., Coelho, M.M., Collares-Pereira, M.J., 2001. Evolution in action through hybridization in an Iberian freshwater fish: a genetic review. Genetica 111, 375-385.

Arbogast, B.S., Edwards, S.V., Wakeley, J., Beerli, P., Slowinski, J.B., 2002. Estimating divergence times from molecular data on phylogenetic and population genetic timescales. Annu. Rev. Ecol. Syst. 33, 707-740.

Atamuradov, K.I., 1994. Paleogeography of Turkmenistan, in Biogeography and Ecology of Turkmenistan. In: Fet, V., Atamuradov, K.I. (Eds.), Kluwer Academic Publishers, Dordrecht, Boston, London, pp. 49-64.

Aubekerov, B., Gorbunov, A., 1999. Quaternary permafrost and mountain glaciation in Kazakhstan. Permafrost Perglacial Processes 10, 65-80.

Baig, K.J., 1998. The Amphibian Fauna of Azad Jammu and Kashmir with new record of Paa liebigii. Proc. Pakistan Acad. Sci. 35 (2), $117-121$.

Bailon, S., 2000. Amphibiens et reptiles du Pliocene terminal d'Ahl al Oughlam (Casablanca, Maroc). Geodiversitas 22 (4), 539-558.

Balletto, E., Cherchi, M.A., Gasperetti, J., 1985. Amphibians of the Arabian peninsula. Fauna Saudi Arabia 7, 318-392.

Benn, D.I., Owen, L.A., 2002. Himalayan glacial sedimentary environments: a framework for reconstructing and dating the former extent of glaciers in high mountains. Quatern. Int. (97/98), 3-25.

Beukeboom, L.W., Vrijenhoek, R.C., 1998. Evolutionary genetics and sperm dependent parthenogenesis. J. Evol. Biol. 11, 755-782.

Blair, W.F. (Ed.), 1972. Evolution in the genus Bufo. University Texas Press, Austin, London, pp. 1-459.

Bogaerts, S., 2001. Breeding Brongersma's toad, Bufo brongersmai. Podarcis 2 (3), 81-88.

Bogart, J.P., 1972. Karyotypes. In: Blair, W.F. (Ed.), Evolution in the genus Bufo. Univ. Texas Press Austin, London, pp. 171-232.

Bogart, J.P., 1980. Evolutionary significance of polyploidy in amphibians and reptiles. In: Lewis, W.H. (Ed.), Polyploidy, biological relevance. Basic Life Sciences, 46. Plenum Press, New York, London, pp. 341-378.

Bogart, J.P., 2003. Genetics and systematics of hybrid species. In: Sever, D.M. (Ed.) (vol. 1 of the series: Jamieson, B.G.M. (Ed.), Reproductive biology and phylogeny), Reproductive biology and phylogeny of Urodela. Sci. Publ. Enfield (USA), Plymouth (UK), pp. 109-134.

Bogart, J.P., Klemens, M.W., 1997. Hybrids and genetic interactions of mole salamanders (Ambystoma jeffersonianum and $A$. laterale) (Amphibia: Caudata) in New York and New England. Am. Mus. Novit. 3, 1-78. (Am. Mus. Nat. Hist. New York).

Böhme, G., 1991. Continuity and change in Cenocoic herpetofaunas of Central Europe. Mitt. Zool. Mus. Berl. 67, 85-91.

Böhme, M., 2003. The Miocene climatic optimum: evidence from ectothermic vertebrates of Central Europe. Palaeogeo. Palaeoclimat. Palaeoecolog. 195, 389-401.

Bons, J., Geniez, P., 1996. Amphibiens et reptiles du Maroc (Sahara occidental compris) - Atlas biogeographique. Asociacion Herpetologica Espanola, Barcelona.

Borkin, L.Ya., 1999. Distribution of amphibians in North Africa, Europe, and the former Soviet Union. In: Duellman, W.E. (Ed.), Patterns of distribution of Amphibians. John Hopkins University press, Baltimore, London, pp. 329-420.

Borkin, L.Ya., Eremchenko, V.K., Helfenberger, N., Panfilov, A.M., Rozanov, J.M., 2001. On the distribution of diploid, triploid and tetraploid green toads in south-eastern Kazakhstan. Russ. J. Herpetol. 8 (1), 45 53 [see also erratum in vol. 8 (3), 246].

Butler, R.W.H., McClelland, E., Jones, R.E., 1999. Calibrating the duration of the Messinian salinity crisis in the Mediterranean: linked tectonoclimatic signals in the thrust-top basins of Sicily. J. Geol. Soc., London 156, 827-835.

Castellano, S.C., Giacoma, C., Dujsebayeva, T., Odierna, G., Balletto, E., 1998. Morphometric and advertisement call geographic variation in polyploid green toads. Biol. J. Linn. Soc. 63, 257-281.

Chikvadze, V.M., 1985. Preliminary results of the study of Tertiary amphibians and squamates from Zaisan Basin. In: Darevsky, I.S. (Ed.), 
Voprosy Gerpetologii, 6th All-Union Herpetological Conference. Nauka, Leningrad, pp. 234-235 [in Russian].

Claessens, L., 1997. On the Herpetofauna of some Neogene Mediterranean localities and the occurrence of Palaeobatrachus and Bufo (Amphibia, Anura) of the Lower Miocene of Turkey. J. Vert. Paleont. 17 (3), 39A.

Clement, M., Posada, D., Cradell, K.A., 2000. TCS: a computer program to estimate gene genealogies. Mol. Ecol. 9 (10), 1660-16657.

Contreras, L.C., Torres-Mura, J.C., Spontorno, A.E., 1990. The largest chromosome number for a mammal, in a South American desert rodent. Experientia 46, 506-508.

Coyne, J.A., Orr, H.A., 2004. Speciation. Sinauer Assoc. Inc., Sunderland, Mass.

Cunha, C., Coelho, M.M., Carmona, J.A., Doadrio, I., 2004. Phylogeographical insights in the origins of the Squalius alburnoides complex via multiple hybridization events. Mol. Ecol. 13, 2807-2817.

Darvesky, I.S., Danelyan, F.D., Sokolova, T.M., Rozanov, Yu.M., 1989. Intraclonal mating in the parthenogenetic lizard species Lacerta unisexualis Darevsky. In: Dawley, M., Bogart J.P. (Eds.), Evolution and Ecology of Unisexual Vertebrates. Mus. Bull. 466. Univ. State New York, New York State Museum, Albany, pp. 228-235.

Dawley, R.M., Bogart, J.P. (Eds.) 1989. Evolution and Ecology of Unisexual Vertebrates. Mus. Bull. 466. Univ. State New York, State Educ. Dep., New York State Museum, Albany, New York.

Dehal, P., Boore, J.L., 2005. Two Rounds of whole genome duplication in the ancestral vertebrate. PLoS 3 (10), e314.

Dobson, M., Wright, A., 2000. Faunal relationships and zoogeographical affinities of mammals in north-west Africa. J. Biogeogr. 27, 417-424.

Dubois, A., Martens, J., 1977. Sur les crapauds du groupe de Bufo viridis (Amphibiens, Anoures) de l'Himalaya occidental (Cachmire et Ladakh). Bull. Soc. Zool. France 102, 459-465.

Dujsebayeva, T., Castellano, S., Magni, P., Odierna, G., 2003. New data on distribution of amphibians and reptiles in the Aral Sea Basin and surrounding Kazakhstan, Part I. The green toads of Bufo viridis complex (Amphibia: Anura). Selevinia (The zoological year-book of Kazakhstan), 60-65.

Evans, B.J., Kelley, D.B., Tinsley, R.C., Melnick, D.J., Cannatella, D.C., 2004. A mitochondrial DNA phylogeny of African clawed frogs: phylogeography and implications for polyploid evolution. Mol. Phylogenet. Evol. 33, 197-213.

Evans, B.J., Kelley, D.B., Melnick, D.J., Cannatella, D.C., 2005. Evolution of RAG-1 in polyploid clawed frogs. Mol. Biol. Evol. 22 (5), 1193 1207.

Flindt, R., Hemmer, H., 1968. Über Bufo viridis im Vorderen Orient. [On B. viridis in the Middle East]. Salamandra (Frankf./M.).

Frost, D.R. (Ed.), 1985. Amphibian species of the world. A taxonomic and geographical reference. Allen Press and Ass. of Systematics Collections Lawrence, Kansas.

Frost, D.R., 2004. Amphibian Species of the World: an Online Reference. Version 3.022 August, 2004). Database <http://research.amnh.org/ herpetology/amphibia/index.php/>. Am. Mus. Nat. Hist., New York, USA.

Fu, J., Weadicka, C.J., Zengb, X., Wangb, Y., Liub, Z., Zhengb, Y., Lib, C., Huc, Y., 2005. Phylogeographic analysis of the Bufo gargarizans species complex: A revisit. Mol. Phylogenet. Evol. 37, 202-213.

Furlong, R.F., Holland, P.W.H., 2002. Were vertebrates octoploid? Phil. Trans. R. Soc. Lond. B 357, 531-544.

Garcia-Paris, M., Montori, A., Herrero, P., 2004. Amphibia, Lissamphibia. Fauna Iberica, vol. 24. Museo Nacional de Ciencias Naturales Consejo Superior de Investigaciones Cientificas, Madrid.

Gasc, J.P., Cabela, A., Crnobrnja-Isailovic, J., Dolmen, D., Grossenbacher, K., Haffner, P., Lescure, J., Martens, H., Martínez Rica J.P., Maurin, H., Oliveira, M.E., Sofianidou, T.S., Veith, M., Zuiderwijk A., (Eds.), 1997. Atlas of amphibians and reptiles in Europe. Collection Patrimoines Naturels, Paris, 29, 496 pp.

Goddard, K.A., Megwinoff, O., Wessner, L.L., Giaimo, F., 1998. Confirmation of gynogenesis in Phoxinus eos-neogaeus (Pisces: Cyprinidae). J. Hered. 89, 151-157.

Goebel, A.M., Donelly, J.M., Atz, M.E., 1999. PCR-primers and amplification methods for $12 \mathrm{~s}$ ribosomal DNA, the control region, cytochrome oxidase I, and cytochrome $\mathrm{b}$ in bufonids and other frogs, and an overview of PCR primers which have amplified DNA in amphibians successfully. Mol. Phylogenet. Evol. 11 (1), 163-199.

Gregory, T.R., Mable, B.K., 2005. Polyploidy in animals. In: Gregory, T.R. (Ed.), The evolution of the genome. Elsevier, Amsterdam, Boston, Tokyo, pp. 428-501.

Grillitsch, B., Grillitsch, H., Splechtna, H., 1989. The tadpole of Bufo brongersmai Hoogmoed 1972. Amphibia-Reptilia 10, 215-229.

Günther, R., 1990. Die Wasserfrösche Europas. In: Ziemsen, A. (Ed.), Die Neue Brehm-Bücherei, vol. 600. Wittenberg, 288 pp [in German].

Günther, R., Uzzell, T., Berger, L., 1979. Inheritance patterns in triploid Rana "esculenta" (Amphibia, Salientia). Mitt. Zool. Mus. Berl. 55 (1), 35-57.

Herrero, P., Lopez-Jurado, L.F., Arano, B., Garcia-Paris, M., 1993. Karyotype analysis and nuclear DNA content of Bufo brongersmai Hoogmeed. J. Herpetol. 27 (4), 463-465.

Hewitt, G.M., 2004. Genetic consequences of climatic oscillations in the Quaternary. Phil. Trans. R. Soc. Lond. B 359, 183-195.

Huelsenbeck, J.P., Rannala, B., 1997. Phylogenetic methods come of age: Testing hypotheses in an evolutionary context. Science 276, 227-232.

Huelsenbeck, J.P., Ronquist, F., 2001. MrBayes: Bayesian inference of phylogenetic trees. Bioinformatics 17 (8), 754-755.

Inger, R.F., 1972. Bufo of Eurasia. In: Blair, W.F. (Ed.), Evolution in the genus Bufo. Univ. Texas Press, Austin, London, pp. 102-118.

Jaeger, J.J., Coiffait, B., Tong, H., Denys, C., 1987. Rodent extinctions following Messinian faunal exchanges between western Europe and Northern Africa. Mém. Soc. Géol. France, N.S. 150, 153-158.

Jaillon, O., Aury J.-M., Brunet F. [+58 more], 2004. Genome duplication in the teleost fish Tetraodon nigroviridis reveals the early vertebrate protokaryotype. Nature 431, 946-957.

Kamp, U., Haserodt, K., 2004. Quarternary glaciations in the high mountains of northern Pakistan. In: Ehlers, J., Gibbard, P.L. (Eds.), Quaternary glaciations, extent and chronology, part III: South America, Asia, Africa, Australasia, Antarctica. In: Rose, J. (Ed.), Series: Development in Quaternary Science, vol. 2, Elsevier, Amsterdam, pp. 293-311.

Karakousis, Y., Kyriakopoulou-Sklavounou, P., 1995. Genetic and morphological differentiation among populations of the green toad Bufo viridis from Northern Greece. Biochem. Syst. Ecol. 23 (1), 39-45.

Kawamura, T., 1984. Polyploidy in Amphibians. Zool. Sci. 1, 1-15.

King, M., 1990. Amphibia. In: John, B., Kayano H., Levan A. (Eds.), Animal Cytogenetics, vol. 4. Chordata. Gebrüder Borntraeger, Berlin, Stuttgart.

Kordikova, E.G., 1998. Herpetofaunas of Kazakhstan in the Paleozoic, Mesozoic and Cenozoic. Vestnik KazGU [Kazakhskoi gosudarstvennoi universitet], ser. Biologiceskaya 6, 61-109.

Krjigsman, W., Hilgen, F.J., Raffi, I., Sierro, F.J., Wilson, D.S., 1999. Chronology, causes and progression of the Messinian Salinity Crisis. Nature 400, 652-655.

Kuhner, M.K., Yamato, J., Felsenstein, J., 1998. Maximum likelihood estimation of population growth rates based on the coalescent. Genetics $149,429-434$

Kuzmin, S.L. 1999. The amphibians of the former Soviet Union. Pensoft, Sofia, $538 \mathrm{pp}$

Le Comber, S.C., Smith, C., 2004. Polyploidy in fishes: patterns and processes. Biol. J. Linn. Soc. 82, 431-442.

Liu, W.Z., Lathrop, A., Fu, J.Z., Yang, D.T., Murphy, R.W., 2000. Phylogeny in east Asian bufonids inferred from mitochondrial DNA sequences (Anura: Amphibia). Mol. Phylogenet. Evol. 14 (3), 423-435.

Mable, B.K., 2004. 'Why polyploidy is rarer in animals than in plants': myths and mechanisms. Biol. J. Linn. Soc. 82, 453-466.

Macey, J.R., Schulte, J.A., Ananjeva, N.B., Larson, A., Rastegar-Pouyani, N., Shammakov, S.M., Papenfuss, T.J., 1998a. Phylogenetic relationships among agamid lizards of the Laudakia caucasica species group: testing hypothesis of biogeographic fragmentation and an area cladogram for the Iranian Plateau. Mol. Phylogenet. Evol. 10 (1), 118-131.

Macey, R.J., Schulte, J.A., Larson, A., Fang, Z., Wang, Y., Tuniyev, B.S., Papenfuss, T.J., 1998b. Phylogenetic relationships of toads in the Bufo bufo species group from the eastern escarpment of the Tibetan Plateau: A case of vicariance and dispersal. Mol. Phylogenet. Evol. 9 (1), 80-87. 
Macey, J.R., Wang, Y., Ananjeva, N.B., Larson, A., Papenfuss, T.J., 1999. Vicariant Patterns of fragmentation among gekkonid lizards of the genus Teratoscincus produced by the Indian collision: A molecular phylogenetic perspective and an area cladogram for Central Asia. Mol. Phylogenet. Evol. 12 (3), 320-332.

Macey, J.R., Schulte, J.A., Kami, H.G., Ananjeva, N.B., Larson, A., Papenfuss, T.J., 2000. Testing hypothesis of vicariance in the agamid lizard Laudakia caucasia from mountain ranges of he Northern Iranian Plateau. Mol. Phylogenet. Evol. 14 (3), 479-483.

Mavárez, J., Salazar, C.A., Bermingham, E., Salcedo, C., Jiggins, C.D., Linares, M., 2006. Speciation by hybridization in Heliconius butterflies. Nature 441, 868-871.

Maxson, L.R., 1981. Albumin evolution and its phylogenetic implications in toads of the genus Bufo. II. Relationships among Eurasian Bufo. Copeia 1981, 579-583.

Mazik, E. Yu., Kadyrova, B.K., Tokotosunov, A.T., 1976. Osobennosti kariotipa zelenoi zhaby (Bufo viridis) v Kirgizii. Zool. Zh. 55, 17401742 [in Russian].

McLysaght, L., Hokamp, K., Wolfe, K.H., 2002. Extensive genome duplication during early chordate evolution. Nat. Genet. 31, 200-204.

Meyer, A., Schartl, M., 1999. Gene and genome duplications in vertebrates: the one-to-four (-to-eight in fish) rule and the evolution of novel gene functions. Curr. Opin. Cell Biol. 11, 699-704.

Mezhzherin, S.V., Pisanets, E.M., 1995. Genetic structure and origin of the tetraploid toad Bufo danatensis Pisanets, 1978 (Amphibia, Bufonidae) from Central Asia: Differentiation of geographic forms and genetic relationship between diploid and tetraploid species. Genetika 31, 342352 [in Russian].

Mlynarski, M., Böhme, G., Ullrich, H., 1978. Amphibian and reptilian remains from the late Pleistocene cover layer sequence of the Burgtonna travertine in Thueringia. Quatärpaläontologie 3, 223-226.

Morjan, C.L., Rieseberg, L.H., 2004. How species evolve collectively: implications of gene flow for the spread of advantageous alleles. Mol. Ecol. 13, 1341-1356.

Nei, M., Li, W., 1979. Mathematical model for studying variation in terms of restriction endonucleases. Proc. Natl. Acad. Sci. USA 76, 5269-5273.

Nevo, E., 1972. Climatic adaption in size of the green toad (Bufo viridis). Israel J. Med. Sci. 8, 1010.

Odierna, G., Aprea, G., Capriglione, T., Castellano, S., Balletto, E., 2004. Evidence for chromosome and pst I satellite DNA family evolutionary stasis in the Bufo viridis group (Amphibia, Anura). Chromosome Res. 12, 671-681.

Ogielska, M., Kierzkowski, P., Rybacki, M., 2004. DNA content and genome composition of diploid and triploid water frogs belonging to the Rana esculenta complex (Amphibia, Anura). Can. J. Zool. 82, 1894-1901.

Ohno, S., 1970. Evolution by genome duplication. Springer, New York.

Owen, L., Finkel, R.C., Caffee, M.W., Gualtieri, L., 2000a. Timing and multiple late Quaternary glaciations in the Hunza valley, Karakoram, NPakistan: Defined by cosmogenic radionucleide dating of moraines. Geol. Soc. Bull. 114 (5), 593-604.

Owen, L., Kamp, U., Spencer, J.Q., Haserodt, K., 2000b. Timing and style of late Quaternary glaciation in the Eastern Hindukush, Chitral, northern Pakistan: a review and revision of the glacial chronology based on new optically stimulated luminescence dating. Quatern. Int., 41-55.

Patterson, N., Richter, D.J., Gnerre, S., Lander, E.S., Reich, D., 2006. Genetic evidence for complex speciation of humans and chimpanzees. Nature doi:10.1038/nature04789.

Pauly, G.B., Hillis, D.M., Cannatella, D.C., 2004. The history of Nearctic colonization: molecular phylogentics and biogeography of Nearctic toads (Bufo). Evolution 58 (11), 2517-2535.

Petit, R.J., Aguinagalde, I., Beaulieu, J.-L., Bittkau C., Brewer, S. [+12 more], 2003. Glacial refugia: hotspots of genetic diversity. Science 300, 1563-1565.

Pisanets, E.M., 1978. O novom poliploidnom vide zhab Bufo danatensis Pisanets. sp. n. iz Turkmenii. Doklady Akad. Nauk Ukrainskoi SSR, Ser. B, geol., chim. i biolog. nauki 3, 280-284 [in Russian].

Plötner, J., 2005. Die Westpaläarktischen Wasserfrösche. Beiheft Z. Feldherp. 9, Laurenti, Bielefeld, 1-160 pp. [in German].
Posada, D., Crandall, K.A., 1998. Modeltest: testing the model of DNA substitution. Bioinformatics 14 (9), 817-818.

Pramuk, J.B., 2006. Phylogeny of South American Bufo (Anura: Bufonidae) inferred from combined evidence. Zool. J. Linn. Soc. 146, 407-452.

Proskuriakova, G.M., 1971. Some general features of the Bolshoi Balkhan flora. Ann. Nathist. Mus. Wien 75, 203-208.

Ptacek, M.B., Gerhardt, H.C., Sage, R.D., 1994. Speciation by polyploidy in treefrogs: multiple origins of the tetraploid, Hyla versicolor. Evolution 48 (3), 898-908.

Rab, P., Rabova, M., Bohlen, J., Lusk, S., 2000. Genetic differentiation of the two hybrid diploid-polyploid complexes of loaches, genus Cobitis (Cobitidae) involving C. taenia, C. elongatoides and C. spp. in the Czech Republic: Karyotypes and cytogenetic diversity. Folia Zool. 49 (Suppl. 1), 55-66.

Rage, J.-C., 2003. Oldest Bufonidae (Amphibia, Anura) from the Old World: A bufonid from the Paleocene of France. J. Vert. Paleont. 23 (2), 462-463.

Rage, J.-C., Rocek, Z., 2003. Evolution of anuran assemblages in the Tertiary and Quaternary of Europe, in context to paleoclimate and paleogeography. Amphibia-Reptilia 24, 133-167.

Rocek, Z., Rage, L.C., 2000. Tertiary anura of Europe, Africa, Asia, North America and Australia. In: Heatwole H., Carrol R.L. (Eds.), Amphibian Biology. Palaeontology, vol. 4. Surrey Beatty and Sons, USA, pp. $1332-1337$.

Rögl, F., 1998. Paleogeographic considerations for Mediterranean and Paratethys seaways (Oligocene to Miocene). Ann. Naturhist. Mus. Wien 99A, 279-310.

Rögl, F., 1999. Circum-Mediterranean Miocene Paleogeography. In: Rössner, G., Heissig, K. (Eds.), The Miocene Land Mammals of Europe. Dr. Friedrich Pfeil, Munich, pp. 39-48.

Sanchiz, B., 1997. Factores causales de biodiversidad: especiacion y migracion en la batrachofauna europea. In: Aguirre, E., Morales, J., Soria, D. (Eds.), Registros fosiles e hitoria de la terra. Complutense, Madrid, pp. 185-206.

Sanchiz, B., 1998. Salientia. In: Wellnhofer, P. (Ed.), Part 4 of Encyclopedia of Paleoherpetology. Munich, pp. 1-276.

Schleich, H.H., Kästle, W., Kabisch, K., 1996.Amphibians and Reptiles of North Africa Koeltz Scientific books, Koenigstein, Germany.

Schmid, M., 1980. Chromosome evolution in Amphibia. In: Müller, H. (Ed.), Cytogenetics of Vertebrates. Birkhäuser, Basel, Boston, Stuttgart, pp. 4-27.

Schneider, S., Roesseli, D., Excoffier L., 2000. Arlequin ver 2.000. A software for population genetic analysis. <http://anthro.unigen.ch/ arlequin/>.

Schultz, R.J., 1969. Hybridization, unisexuality, and polyploidy in the teleost Poeciliopsis (Poecilidae) and other vertebrates. Am. Nat. 103, 606-619.

Schultz, R.J., 1980. Role of polyploidy in the evolution of fishes. In: Lewis, W.H. (Ed.), Polyploidy, biological relevance, Basic Life Sciences. Plenum Press, New York, London, pp. 341-378.

Simon, J.-C., Delmotte, F., Rispe, C., Crease, T., 2003. Phylogenetic relationships between parthenogens and their sexual relatives: the possible routes to parthenogenesis in animals. Biol. J. Linn. Soc. 79, 151-163.

Stöck, M., 1997. Untersuchungen zur Morphologie und Morphometrie diund tetraploider Grünkröten (Bufo viridis-Komplex) in Mittelasien (Amphibia: Anura: Bufonidae). Zool. Abh. Staatl. Mus. Tierkd. Dresden 49, 193-222.

Stöck, M., 1998a. Mating call differences between diploid and tetraploid green toads (Bufo viridis complex) in Middle Asia. Amphibia-Reptilia 19, 29-42.

Stöck, M., 1998b. Tetraploid toads (Bufo viridis complex) from northwestern China and preliminary taxonomic conclusions for Bufo nouettei Mocquard 1910. Z. Feldherp. (Bochum) 5, 139-166.

Stöck, M., Lamatsch, D.K., 2002. Triploide Wirbeltiere-Wege aus der Unfruchtbarkeit oder Eingeschlechtigkeit [Triploid VertebratesWays to escape from infertility and unisexuality]. Naturwiss. Rundsch. 55 (7), 349-358 [in German].

Stöck, M., Schmid, M., Steinlein, C., Grosse, W.-R., 1999. Mosaicism in somatic triploid specimens of the Bufo viridis complex in the 
Karakoram with examination of calls, morphology and taxonomic conclusions. Ital. J. Zool. (Modena) 66 (3), 215-232.

Stöck, M., Günther, R., Böhme, W., 2001a. Progress towards a taxonomic revision of the Asian Bufo viridis group: Current status of nominal taxa and unsolved problems (Amphibia: Anura: Bufonidae). Zool. Abh. Staatl. Mus. Tierkunde Dresden 51, 253-319.

Stöck, M., Frynta, D., Grosse, W.-R., Steinlein, C., Schmid, M., 2001b. A review of the distribution of diploid, triploid and tetraploid green toads (Bufo viridis complex) in Asia including new data from Iran and Pakistan. Asiatic Herp. Res. (Berkeley) 9, 77-100.

Stöck, M., Bretschneider, P., Grosse, W.-R., 2001c. [,2000“]. The mating call and male release call of Bufo raddei Strauch, 1876 with some phylogenetic implications. Russ. J. Herp. 7 (3), 215-226.

Stöck, M., Lamatsch, D.K., Steinlein, C., Epplen, J.T., Grosse, W.-R., Hock, R., Klapperstück, T., Lampert, K.P., Scheer, U., Schmid, M., Schartl, M., 2002. A bisexually reproducing all-triploid vertebrate. Nat. Genet. 30 (3), 325-328.

Stöck, M., Steinlein, C., Lamatsch, D.K., Schartl, M., Schmid, M., 2005. Multiple origins of tetraploid taxa in the Eurasian Bufo viridis subgroup. Genetica 124, 255-272.

Sumida, M., Kaneda, H., Kato, Y., Kanamori, Y., Yonekawa, H., Nishioka, M., 2000. Sequence variation and structural conservation in the d-loop region and flanking genes of mitochondrial DNA from Japanese pond frogs. Genes Genet. Syst. 75, 79-92.

Suomalainen, E., Saura, A., Lokki, J., 1987. Cytology and evolution in parthenogenesis. CRC Press, Boca Raton, Florida.

Svartman, M., Stone, G., Stanyon, R., 2005. Molecular cytogenetics discards polyploidy in mammals. Genomics $85,425-430$.

Swofford, D.L., 2002. PAUP*: Phylogenetic Analysis Using Parsimony (* and other methods). Version 4. Sinauer Associates, Sunderland, MA.

Taberlet, P., Fumagalli, L., Wust-Saucy, A.-G., Cosson, J.-F., 1998. Comparative phylogeography and postglacial colonization routes in Europe. Mol. Ecol. 7, 453-464.

Tajima, F., 1989. Statistical methods for testing the neutral mutation hypothesis by DNA polymorphism. Genetics $123,585-595$.
Tandy, M., Bogart, J.P., Largen, M.J., Feener, D.J., 1982. A tetraploid species of Bufo (Anura, Bufonidae) from Ethiopia. Mon. Zool. Italiano, N.S., Suppl. XVII (1), 1-79.

Tandy, M., Bogart, J.P., Largen, M.J., Feener, D.J., 1985. Variation and evolution in Bufo kerinyagae Keith, B. regularis Reuss and B. asmarae Tandy et al. (Anura, Bufonidae). Mon. Zool. Italiano, N.S., Suppl. XX (12), 211-267.

Taylor, J.S., Raes, J., 2005. Duplication and divergence: The Evolution of new genes and old ideas. Annu. Rev. Genet. 38, 615-643.

Tchernov, E., 1988. The biogeographical history of the southern Levant. In: Yom-Tov, Y., Tchernov, E. (Eds.), The zoogeography of Israel. W. Junk Publ. (Kluwer Acad. Publ. Group), Dordrecht, Boston, Lancaster, pp. $159-250$.

Tsigenopoulos, C.S., Rab, P., Naran, D., Berrebi, P., 2002. Mutiple origins of polyploidy of southern African barbs (Cyprinidae) as inferred from mtDNA markers. Heredity 88, 466-473.

Made, J. van der, 1999. Intercontinental relationship Europe-Africa and the Indian subcontinent. In: Rössner G., Heissig, K. (Eds.), The Miocene Land Mammals of Europe. Verlag Dr. Friedrich Pfeil, Munich, pp. 457-472.

Vasilev, V.P., Akimova, N., Emelyanova, N.G., Pavlov, D.A., Vasileva, E.D., 2003. Reproductive capacities in the polyploid of spined loaches from the unisexual-bisexual complex, occurred in the Moscow River. Folia Boil. (Kraków) 51, 67-73.

Vences, M., Wake, D.B., (in press.). Speciation, species boundaries and phylogeography of amphibians. In: Heatwole, H., (Ed.), Amphibian Biology, vol. 7.

Vinogradov, A.E., Borkin, L.J., Günther, R., Rosanov, J.M., 1990. Genome elimination in diploid and triploid Rana esculenta males: cytological evidence from DNA flow cytometry. Genome 33 (5), 619-627.

Wares, J.P., Cunningham, C.W., 2001. Phylogeography and historical ecology of the North Atlantic intertidal. Evolution 55, 2455-2469.

Zhou, L., Wang, Y., Gui, J.-F., 2000. Genetic evidence for gonochoristic reproduction in Silver Crucian Carp (Carassius auratus gibelio Bloch) as revealed by RAPD assays. J. Mol. Evol. 51, 498-506. 